\title{
Common Themes in Zoonotic Spillover and Disease Emergence: Lessons Learned from Bat- and Rodent-Borne RNA Viruses
}

\author{
Evan P. Williams ${ }^{1}\left(\right.$, Briana M. Spruill-Harrell ${ }^{1}$, Mariah K. Taylor ${ }^{1}{ }^{\oplus}$, Jasper Lee ${ }^{1}$, Ashley V. Nywening ${ }^{2}{ }^{\oplus}$, \\ Zemin Yang ${ }^{3}$, Jacob H. Nichols ${ }^{1}$, Jeremy V. Camp ${ }^{4}\left(\mathbb{D}\right.$, Robert D. Owen ${ }^{5,6}{ }^{\mathbb{D}}$ and Colleen B. Jonsson ${ }^{1, * \mathbb{C}}$
}

check for

updates

Citation: Williams, E.P.;

Spruill-Harrell, B.M.; Taylor, M.K.;

Lee, J.; Nywening, A.V.; Yang, Z.;

Nichols, J.H.; Camp, J.V.; Owen, R.D.;

Jonsson, C.B. Common Themes in

Zoonotic Spillover and Disease

Emergence: Lessons Learned from

Bat- and Rodent-Borne RNA Viruses.

Viruses 2021, 13, 1509. https:/ /

doi.org/10.3390/v13081509

Academic Editors: James Strong,

David Safronetz and Juan C.

De la Torre

Received: 14 April 2021

Accepted: 28 July 2021

Published: 31 July 2021

Publisher's Note: MDPI stays neutral with regard to jurisdictional claims in published maps and institutional affiliations.

Copyright: (c) 2021 by the authors. Licensee MDPI, Basel, Switzerland. This article is an open access article distributed under the terms and conditions of the Creative Commons Attribution (CC BY) license (https:/ / creativecommons.org/licenses/by/ $4.0 /)$.
1 Department of Microbiology, Immunology and Biochemistry, The University of Tennessee Health Science Center, Memphis, TN 38163, USA; ewilli99@uthsc.edu (E.P.W.); bspruill@uthsc.edu (B.M.S.-H.); mtay1121@uthsc.edu (M.K.T.); jlee175@uthsc.edu (J.L.); jnicho60@uthsc.edu (J.H.N.)

2 Department of Clinical Pharmacy and Translational Sciences, The University of Tennessee Health Science Center, Memphis, TN 38163, USA; ashnywe@uthsc.edu

3 Department of Cell and Molecular Biology, St. Jude's Children's Hospital, Memphis, TN 38105, USA; zemin.yang@stjude.org

4 Center for Virology, Medical University of Vienna, 1090 Vienna, Austria; jeremy.camp@meduniwien.ac.at

5 Centro para el Desarrollo de Investigaciones Científicas, Asunción C.P. 1371, Paraguay; rowen@pla.net.py

6 Department of Biological Sciences, Texas Tech University, Lubbock, TX 79409, USA

* Correspondence: cjonsson@uthsc.edu; Tel.: +1-(901)-448-1870

\begin{abstract}
Rodents (order Rodentia), followed by bats (order Chiroptera), comprise the largest percentage of living mammals on earth. Thus, it is not surprising that these two orders account for many of the reservoirs of the zoonotic RNA viruses discovered to date. The spillover of these viruses from wildlife to human do not typically result in pandemics but rather geographically confined outbreaks of human infection and disease. While limited geographically, these viruses cause thousands of cases of human disease each year. In this review, we focus on three questions regarding zoonotic viruses that originate in bats and rodents. First, what biological strategies have evolved that allow RNA viruses to reside in bats and rodents? Second, what are the environmental and ecological causes that drive viral spillover? Third, how does virus spillover occur from bats and rodents to humans?
\end{abstract}

Keywords: spillover; zoonosis; RNA viruses; bats; rodents; outbreak; reservoir

\section{Introduction}

Globalization, environmental and anthropogenic changes provide ample opportunities for spillover and emergence of zoonotic diseases [1-3]. The term zoonosis was first coined in the latter half of the 19th century by Rudolf Virchow, who noted the relationship of humans and animals in the occurrence of infectious diseases [4]. Today, we recognize that greater than half of all human infectious diseases are zoonotic, a majority of which originated through the cross-species transmission of RNA viruses from wildlife to humans [5-8]; and, at present, we know of more than 224 RNA viruses that cause human disease with $88 \%$ of these being zoonotic in nature $[9,10]$. Of those zoonotic viruses that have spilled over, only a few have successfully adapted to humans and resulted in pandemics in the past two centuries, such as the $1918 \mathrm{H} 1 \mathrm{~N} 1$ influenza A virus, human immunodeficiency virus (HIV), hepatitis $\mathrm{C}$ virus (HCV), and severe acute respiratory syndrome-coronavirus-2 (SARS-CoV-2). The 1918 influenza pandemic, which reached a global death toll of up to 100 million people, began as a spillover of an avian influenza H1N1 virus from a bird or some other animal such as pigs [11]. In the case of HIV, which has resulted in approximately 32.7 million deaths from AIDS-related illnesses (through the end of 2019), the ancestral virus spilled over from chimpanzees to humans [12]. The original reservoir of HCV, a virus 
that infects over 70 million worldwide, is still unknown. Viruses belonging to the same Hepacivirus genus have been isolated from reservoirs such as dogs, rodents, and horses [13]. The coronavirus disease 2019 (COVID-19) pandemic caused by SARS-CoV-2 may have started with the spillover of the virus from a bat to an intermediate host [14,15]; but neither the reservoir nor any intermediate host has been confirmed yet.

Most viruses that spillover from wildlife to humans do not typically result in pandemics [7]. More commonly, following infection, humans are "dead-end" hosts, and the virus is not transmitted further from person to person. Typically, these outbreaks are limited to the geographic distribution of the reservoir, but collectively, they have resulted in hundreds of thousands of infections and case fatalities. Some of the more notable, and geographically bound, wildlife to human outbreaks involves viruses harbored by rodents such as hantaviruses (e.g., Hantaan orthohantavirus (HTNV) and Sin Nombre orthohantavirus $(\mathrm{SNV})$ ) and arenaviruses (e.g., Machupo mammarenavirus (MACV), Lassa mammarenavirus (LASV), and Argentinian mammarenavirus (formerly Junin virus (JUNV))) found circulating in the Americas or Africa (Supplementary Table S1). While bats have a much greater geographical range, human outbreaks of viruses carried by bats such as Nipah henipavirus $(\mathrm{NiV})$ and Hendra henipavirus $(\mathrm{HeV})$ are limited to the geographical range of the bat species (Supplementary Table S2).

In this review, we focus on three questions regarding zoonotic viruses that originate in bats and rodents. First, we discuss biological strategies that have evolved that allow RNA viruses to reside in bats and rodents. Second, we look at some of the environmental and ecological causes that drive spillover. Third, we discuss how spillover occurs from bats and rodents to humans by highlighting some shared and unique characteristics of previous epizootic events.

\section{What Biological Strategies Have Evolved That Allow RNA Viruses to Reside in Bats and Rodents?}

The two most abundant and globally distributed mammalian groups are rodents (order Rodentia) followed by bats (order Chiroptera). According to the Mammal Diversity Database maintained by the American Society of Mammologists, there are 2590 extant species within the Rodentia and 1430 extant species within the Chiroptera. Together, these represent $63 \%$ of the 6410 mammalian species known to exist today. Orders Rodentia and Chiroptera diverged approximately 96 million years ago (MYA) according to the most recent available published data (65 studies ca. December 2020) in TimeTree [16,17]. Both mammalian orders have been cited as harboring proportionally high richness of pathogenic viruses [8], and this may be directly related to the high diversity in these two mammalian taxa. The two families known to harbor zoonotic RNA viruses within the order Rodentia are Muridae and the Cricetidae with 843 and 809 species, respectively [18]. Over 50\% of rodentborne zoonotic viruses are members of two families, Hantaviridae and Arenaviridae [19]. Chiroptera is the second most species-rich group of mammals with 21 families [20]. Hence, it is not surprising that over 10,000 RNA virus sequences have been identified in various bat species, several of which are known to cause human disease [21-25]. Viral sequences noted in bats include Astroviridae, Coronaviridae, Circoviridae, Adenoviridae, Filoviridae, Parvoviridae, Poxviridae, Picornaviridae, and Rhabdoviridae [24,26-33]. Of these, only a small percentage of viruses harbored by bats from the rhabdoviruses, filoviruses, paramyxoviruses, and coronaviruses have been associated with disease and outbreaks in human populations. In addition, although bats are reservoirs of several viruses that have been responsible for serious outbreaks, models have shown that viruses harbored by bats are no more likely to be zoonotic than viruses that are harbored or transmitted by rodents or other hosts [19]. For some viruses in the genus Ebolavirus, bats are the presumptive main reservoir, but have yet to be definitively confirmed [34-37].

In the following section, we discuss how biological factors and lifestyle traits contribute to the ability of bats and rodents to serve as a reservoir for an RNA virus. For bat and rodent reservoirs of RNA viruses, multiple characteristics may contribute to their ability to serve as a reservoir [38-41]. The transmission of bat-borne viruses to humans through 
an intermediary host further complicates the biology. Moreover, various combinations of strategies have evolved that are not universal across all virus-reservoir host relationships, which include but are not limited to, limiting the pathogenesis of the viral infection, the ability of the virus-reservoir interplay to modulate the immune response such that the virus may persist, the behavioral and demographic characteristics of bats and rodents that promote endemic maintenance of the viruses they harbor, and the inherent genetic plasticity of RNA viruses. There is a lack of literature for many viruses in conjunction with their natural reservoir host in each of these areas, so we present examples of key areas of research that would benefit from continued research in the natural reservoir host and in their intermediate spillover hosts.

\subsection{Pathogenesis of the Viral Infection}

Numerous studies have reported that with some exceptions (e.g., lyssaviruses in bats, mammarenaviruses in rodents), many RNA viruses may infect and persist in bats and rodents without causing disease [42-46]. The ability of a mammal to carry a virus while healthy would contribute to maintenance and spread of the virus in the population. However, as stated, there are also reports of host reservoirs of viruses that experience disease or a loss in fitness. For example, pathology of bats following experimental infection with rabies viruses in the genus, Lyssavirus, has been reported [47-49]. However, in one report, viral antigen was found in the brain with no apparent pathology [50]. In addition to rabies, pathology (morbidity and mortality) has been demonstrated following experimental infection of Artibeus jamaicensis, the Jamaican fruit-eating bat, with a high dose (not the low dose) of Tacaribe mammarenavirus (TCRV) [51]. TCRV has been isolated from 11 species of bats in Trinidad. However, whether Jamaican fruit-eating bat is the "real" reservoir of TCRV remains to be seen-in fact, fruit bats, in general, may not be reservoirs as persistent infection with shedding has yet to be demonstrated [52]. In studies of rodent reservoirs, there is evidence of some disease in the natural reservoir. Anemia, splenomegaly, and decreased survival have been observed in MACV-infected Calomys callosus (large vesper mouse) [53]. In addition, Webb et al. [53] found the female C. callosus infected with MACV produce only $5 \%$ of the expected number of viable offspring, although having normal estrus cycles. MACV does not cause illness or death in either adult or juvenile mice, and as with other arenaviruses, it infects a variety of cell types. Although infectious virus has been recovered from most major organs, the kidney and spleen are the important target organs for arenavirus replication in rodents $[54,55]$. For rodent reservoirs of hantaviruses, there are examples of a loss in adult survival of animals based on ecological studies of hantaviruses in nature; for example, SNV infection decreases survival of deer mice (Peromyscus maniculatus) in the USA [56] and in bank vole (Myodes glareolus) populations harboring Puumala orthohantavirus (PUUV) surveyed in 55 areas over three years in Finland [57].

Although it is clear that accepted, or presumed reservoir hosts, have an immunological response to virus infection, no apparent disease is detected in experimental or natural infections of certain hosts with viruses such as some coronaviruses, henipaviruses, some hantaviruses, paramyxoviruses, and filoviruses. In an interesting study by Watanabe et al. [58] laboratory Leschenault's rousette bats (Rousettus leschenaultii) were experimentally infected with a wild-caught Betacoronavirus isolated from the lesser short-faced fruit bat (Cynopterus brachyotis) in the Philippines, but these animals showed no clinical signs; viral RNA was only detected in the intestines and not in the liver, kidney, lung, spleen or brain. Similarly, Munster et al. [59] experimentally infected laboratory Jamaican fruit-eating bats with middle east respiratory syndrome-coronavirus (MERS-CoV). Although they could detect shedding of virus, they also reported no clinical signs or pathology. These limited studies of coronaviruses may suggest that an acute infection with virus shedding, but no pathology, may be common in bats, regardless of whether the species is a reservoir host. In other laboratory studies, Egyptian rousette bats, Rousettus aegyptiacus, were infected with Marburg marburgvirus (MARV), and no deaths, overt signs of morbidity, or gross lesions were identified, although, microscopic pathological changes were seen in the liver of infected 
bats [60-64]. In experimental studies by Halpin et al. [65], wild-caught pteropid bats in Australia were infected with the henipaviruses $\mathrm{HeV}$ and $\mathrm{NiV}$. Bats showed virus shedding, but histopathology showed essentially no convincing pathology and no detection of viral antigen. Similarly, Middleton et al. [66] infected grey-headed flying fox bats (Pteropus poliocephalus) with $\mathrm{NiV}$ and reported infection, and pathological examination of tissues did not confirm the presence of the virus with associated pathology so that lesions could not be attributed to viral infection. Woon et al. [67] also infected black flying foxes (Pteropus alecto) with $\mathrm{HeV}$ and showed virus replication in the lungs and an inflammatory response, but no viral shedding nor pathology. Experimental infection of Egyptian rousette bats with the paramyxovirus, Sosuga pararubulavirus, showed infection and virus shedding, but no morbidity nor mortality. However, they report subclinical disease in a subset of tissues [68].

Uniquely for bats, one proposed explanation for the absence of disease for some viral infections is the "flight as fever" hypothesis which posits that the high metabolic rate required for flight stimulates a fever response [39,69]. Daily metabolic surges during flight leads to DNA damage caused by the production of reactive oxygen species [70]. Evidence suggests that during evolution, bats positively selected for genes involved in DNA repair which could have influenced their antiviral immune responses [45,71]. Moreover, to avoid DNA-mediated immunopathology induced during flight, bats have an altered DNA sensing system which may limit viral replication [45,72]. One study suggests virus replication within bat cells does not seem to be temperature dependent [73], suggesting that other characteristics of bats may contribute to enabling them to serve as viral reservoirs.

\subsection{The Host Immune Response}

The ability of bats and rodents to modulate the immune response to viral infection has been an active area of investigation and has been recently reviewed elsewhere $[39,42,45,74,75]$. We highlight a few examples of how viruses interact with specific components of the bat or rodent host immune system, which results in a low level of viral infection or an ability of the host to tolerate viral replication [42,45,74-78]. In general, immune responses of the host play a major role in controlling the viral infection and viruses can exploit these responses in at least one of three ways; (i) immune ignorance, (ii) immune escape, and (iii) immune dysfunction (or exhaustion). The first immune responses to an initial infection occur in three phases in this general order: (i) innate immunity; (ii) early induced immunity; and (iii) adaptive immunity. The goal of each of these responses is the removal of the infectious agent. The innate response plays an important role in detection of the virus during acute stages of infection, which may set the stage for the magnitude of the adaptive responses.

\subsubsection{Interferons (IFN) and Interferon Stimulated Genes (ISGs)}

Most viruses are indirectly sensitive to the induction of IFNs following infection as they induce the upregulation of ISGs; the proteins transcribed from the ISGs actively engage in an antiviral response that directly or indirectly thwart virus replication. Thus, many RNA viruses have evolved strategies to suppress the IFN response and studies suggest similarity of the innate immune signaling pathways in bats and rodents [45,79], although some of their counterparts in bats $[80,81]$ and rodents may function differently. While an active area of research effort, there are few studies of the innate immune response in the many reservoir hosts with the virus they harbor.

Research on bat IFNs suggested diversity in the expression of IFN-alpha. In the black flying fox (reservoir of henipaviruses), and the lesser short-nosed fruit bat IFN-alpha is expressed constitutively [82]. This is not observed in the reservoir of MARV, the Egyptian rousette bat [44]. When compared to ancestral bat species, the IFN gene loci of the black flying fox have contracted whereas the loci of Egyptian rousette bats have diversified [44,82]. Banerjee et al. [80] show that IFN-beta was expressed in big brown bat, Eptesicus fuscus, cells stimulated with poly(I:C); however, tumor necrosis factor-alpha, TNF-alpha, was much lower, and suppressed. In one study with Egyptian rousette bats experimentally infected with MARV, Guito et al. [83] observed a moderate elevation of innate antiviral 
genes, but not cytokines and adaptive immunity-related genes. The authors suggest that Egyptian rousette bats may have evolved a mechanism to control virus replication without induction of the adaptive responses.

Two studies have examined henipaviruses in an immortalized cell line derived from the black flying fox $[84,85]$. The first study suggested that neither $\mathrm{HeV}$ or $\mathrm{NiV}$ infection results in type I and III IFN induction [85]. Both viruses also inhibit interferon signaling. In the second study, the bat cells were treated with supernatant from $\mathrm{CHO}$ cells that contained black flying fox IFN- $\gamma$, and they showed inhibition of virus replication [84]. Examinations of the antiviral response in rodent primary cells using the zoonotic viruses are limited. Studies of hantaviruses and their reservoirs suggest that viral strategies to antagonize the IFN response may vary [86]. Permanent reservoir cell lines that have been developed for the common vole (Microtus arvalis) and bank vole for hantaviruses will provide a valuable tool to exploring virus-reservoir host interaction [87].

The Myxovirus resistance (Mx) proteins are ISGs that are well-studied in in-bred laboratory rodents and shown to directly inhibit many RNA viruses (reviewed in [88]). In wild caught bank voles from various endemic regions in Europe, Dubois et al. [89,90] showed that bank voles from PUUV endemic regions in Europe are more tolerant to infection (higher viral load and delayed antibody production) and have lower ISG and cytokine expression (Mx2, TNF-alpha) compared to bank voles from non-endemic regions.

The Mx1 gene was cloned from three families of bats: Pteropodidae, Phyllostomidae, and Vespertilionidae [91]. Examination of the ability of each of the bat Mx proteins confirmed their ability to reduce replication of Zaire ebolavirus (ZEBOV), vesicular stomatitis virus and Rift Valley fever phlebovirus (RVFV) [91]. However, the Mx from common pipistrelle, Pipistrellus pipistrellus did not show in vitro antiviral activity against RVFV, suggesting functional differences may exist among bats. Direct examination of immune signaling in primary bat cells from a reservoir with the virus they harbor has not been reported for any of these viruses.

\subsubsection{B and T-Cells of Bats and Rodents}

Bats potentially have more VDJ germline gene segments when compared to other mammals and with this lies the potential for bats to have a much larger naive immunoglobulin repertoire. For example, the naive B cell repertoire of the little brown bat (Myotis lucifugus) may potentially be more than 70,000 specificities [92]. Having a much larger repertoire suggests that the bat has a much lower need for somatic hypermutation as well as affinity maturation, leading to lower titers of antibody [92]. The larger repertoire, along with other host responses such as having constitutively expressed IFN reducing viral load, is suggested to explain why bats develop non-robust antibody responses during viral infection allowing for virus replication within the host $[39,82]$.

For some hantaviral infections, the differences in immune responses between reservoir and nonreservoir host are evident in the cytotoxic T lymphocytes (CTL) response (see reviews [93-95]). Seoul orthohantavirus (SEOV) infection of animals without a functional T cell response (e.g., nude rat model) succumb rapidly to infection and diseases suggesting that cell-mediated immunity plays an important role in controlling infection [96]. Mouse models of transient and persistent infection for HTNV [97] were used to analyze the immune response of virus specific CD8+ T cells with MHC tetramers [98]. They showed that N-specific CTLs are strongly regulated and suppressed in this persistently infected mouse model by an unknown mechanism, whereas they are upregulated in the transient model [98]. Viral replication in immune cells such as monocytes, macrophages, or T cells can interfere with or actively suppress immunity and cause persistence [99-101]. Taruishi et al. [98] proposed that the infection of immune cells in the spleen early in infection may result in the suppression of the CTL response. In their persistent animal model experiments, the infection of the spleen correlates with changes in CTL responses. Consequently, due to the downregulation of the CTLs, some of the endothelial cells may remain infected, resulting in a persistent infection in the natural reservoir. In addition, it is hypothesized that 
the regulatory $\mathrm{T}$ cells (Treg) are activated early in the infection process, resulting in decrease in the CTL response $[49,50]$. Treg responses are suggested to enable a persistent infection by suppressing innate immunity, proinflammatory, and effector $\mathrm{T}$ cell activity in SEOVinfected, Norway rats (Rattus norvegicus) and SNV-infected deer mouse [43,77,101-103]. In these studies, Forkhead box P3 gene expression and TGF- $\beta 1$-expressing b1 Treg cells were elevated during persistence, potentially interfering with viral clearance and limiting pathology [99].

As with hantaviruses, the outcome of arenavirus infection is mediated by CTL responses [104-106]. During chronic lymphocytic choriomeningitis virus (LCMV)-Cl13 infection, CTLs become functionally unresponsive or exhausted and are unable to kill virally infected cells or produce antiviral cytokines [107]. Following infection, the functional capacity of CTLs is lost in a hierarchical manner based upon the amount of available antigen [108]. When there is little virus present, CTLs maintain their functional activity, but as viral load increases, all CTL effector functions are lost, including IL-2, TNF- $\alpha$, and IFN- $\gamma$ production [108]. Exhausted LCMV-Cl13-specific CTLs have been shown to upregulate several inhibitory receptors including programmed death-1 (PD-1), lymphocyte activation gene-3 (LAG-3), CD39, and CTL-associated antigen 4 (CTLA-4) [109-113]. It has been suggested that these distinct transcriptional signatures may attenuate signaling through the T cell receptor (TCR), facilitating virus persistence [109]. Recently, the transcription factor TOX was identified as the master regulator of CTL exhaustion during chronic LCMV infection [114]. Moreover, the phenotypic landscape of virus specific CTLs was shown to differ by tissue indicating that tissues, with a higher percentage of functionally exhaustive CTLs may provide a niche for viral persistence [106,115].

For bats, less is known about the T cell responses following viral infection due to the lack of available immunological reagents; however, some groups have begun phenotypically and functionally characterizing bat lymphocyte subsets [116,117]. Gomez et al. [116] identified CTL and Thelper cell populations in the black flying fox using commercially available anti-human/mouse antibodies. They observed an unusually high proportion of CTLs in the spleen, and the T cell populations within the spleen expressed IL-17A, IL-22, and TGF- $\beta$, indicating polarization toward Th17 and Treg cell subsets [116]. These findings suggests that the bat immune system may be armed and ready to thwart viral infection. However, this may not be generalizable across bat species as differences in lymphocyte populations have been reported [117]. Therefore, it would be of great interest to examine the steady state $\mathrm{T}$ cell responses across different wild bat species.

\subsection{Behavioral and Demographic Characteristics}

Unlike most rodents, most species of bats are social, roosting in groups which may range from a few individuals to colonies of many millions of individuals, including the largest single-species aggregations of mammals on earth except for Homo sapiens. Some, such as the straw-colored fruit bat (Eidolon helvum, Family Pteropodidae) are tree-roosters and long-distance migrators. However, the majority of massively colonial species are caveroosters, where they congregate in maximally close proximity [118]. Examples include several species of Egyptian rousette bats, (Rousettus spp., Family Pteropodidae), bentwinged bats, Miniopterus spp. (Miniopteridae), Egyptian slit-faced bats, (Nyteris thebaica, Nycteridae), and several species of free-tailed bats (e.g., Chaerephon plicatus, Mormopterus spp., and Tadarida brasiliensis, Family Molossidae)) [119-124].

Bat species that live in social groups, whether in small groups or in massive colonies with close contact, must play a key role in viral maintenance in the population. In large permanent colonies, viral transmission can potentially follow the birthing cycle of pups, in which an increase in population size with naive (newborn) members reduces herd immunity, allowing for viruses to be reestablished cyclically within a colony $[125,126]$. Recently, individuals of the Egyptian rousette bat were found to self-isolate when immunologically challenged, a behavior which presumably would reduce pathogen contagion within the colony [127]. Notably, the bat species which have been implicated most fre- 
quently as primary reservoirs of zoonotic RNA viruses include Pteropus spp. (NiV, HeV, Menangle pararubulavirus, Tioman pararubulavirus) and Rhinolophus spp. (SARS-CoV related viruses) [128]. These bats are colonial, although not massively so.

Calisher et al. [21] list and discuss many of the viruses associated with bats, as well as several unique features of bats which may enhance their suitability as viral reservoirs. Bats' capacity for flight (mobility, escape from predators), their long evolutionary history and broad taxonomic diversity, diverse population structure (discussed above) and social/colonial strategies, wide geographical distribution and ability to migrate (virus dispersal and spread), their distinctively high longevity, and seasonal hibernation in some temperate species (viral persistence) may all contribute to making them suitable reservoir hosts $[21,69,129-133]$.

As with bats, the behavioral and demographic characteristics of rodents may contribute to their capacity to serve as reservoirs for harboring and maintaining viruses. In comparison, trade-offs between reproduction and lifespan constitute the life-history of rodents. Rodents generally exhibit an r-selected life history, characterized by early sexual maturity and large litter sizes [41], which leaves them vulnerable to resource depletion or climatic variation. Consequently, rodent populations fluctuate with seasonality and climate change, which affects the availability of food resources and, therefore, reproductive activity [134]. This, in turn, impacts the prevalence of some RNA viruses in the population. For example, in areas with large seasonal variations such as the temperate forests of Central Europe, beech mast seedings have been shown to trigger population surges of the bank vole in the following year and correlate with human PUUV outbreaks [135]. Conversely, during periods of drought, when food resources are limited, Mastomys natalensis, natal multimammate mice, the reservoir of LASV, are found in high abundances within human dwellings, which likely drives the higher rate of human LASV infections [136]. Even on a local scale, significant hantaviral seroprevalence differences have been observed in deer mice [137], and microhabitat preferences have been reported to vary seasonally and interannually in two sympatric reservoirs for hantaviruses in Paraguay [138]. Moreover, habitat associations of seropositive individuals differed from the general population of for Akodon montensis [139]. In general, for a virus to persist in a reservoir with short generation time and rapid population turnover, it must be maintained once the virus reaches a persistent and low level of replication. Calisher et al. [140] found evidence that although deer mice individuals typically lived less than a year, a few long-lived persistently infected individuals are the principal trans-seasonal reservoir of SNV.

Some viruses within the Arenaviridae and Hantaviridae persist for the lifetime of the reservoir host, with the viruses present at relatively low levels in the host [141-143]. However, persistent infection as a mechanism of maintenance in the reservoir population may depend on the age of infection. For arenaviruses such as Guanarito mammarenavirus, JUNV, LASV, LCMV, MACV, and Morogoro virus, studies have shown an age-dependency in the duration of infection among reservoir hosts [144-151]. Neonates develop long-term viral persistence, while adults can clear infection [144-151]. The mechanism by which virus persists or is cleared is an area in need of additional investigation. Experimental infection studies of captive bats have shown that some viruses (e.g., $\mathrm{HeV}$ and MARV) have relatively short acute infections lasting days to months, followed by the virus being cleared from the host due to the animal creating antibodies against the virus $[64,65]$.

Regardless of whether the virus persists in its reservoir host, the maintenance of virus in the population depends on the value of the basic reproduction number, $\mathrm{R}_{0}$, which represents the average number of secondary infections possible from a primary infected individual [152]. When the value of $R_{0}$ falls below 1.0 and remains below 1.0 for several generations, then the virus will eventually be eliminated from the population. We have limited information on the $\mathrm{R}_{0}$ of RNA viruses in bat and rodent populations and how it is affected by physiological and environmental factors as well as age, the duration of infection, and animal behavior. 


\subsection{The Inherent Genetic Plasticity of RNA Viruses}

All the viruses discussed herein replicate and transcribe their genomes using an RNA dependent RNA polymerase (RdRp) encoded in their genomes. The RdRp and other viral proteins that support replication do not usually correct misincorporation of nucleosides-an exception being coronaviruses and other members of its family that can proofread mismatched base pairings during replication. Thus, replication and transcription have a high rate of error ranging from $10^{-3}$ to $10^{-5}$ per round of RNA synthesis [153-155]. For a 10,000 nt genome, a $10^{-4}$ rate of misincorporation results in, on average, one error per round of replication. As discussed by Peck and Lauring [156], the measurement of mutation rates is complex, situational and may be biased against lethal mutations, which may result in an underestimate of the mutation rate [156]. Genetic mutations arise randomly through error-prone viral replication machinery and may be selected for in the subsequent cycle of infection and replication if they confer some advantage in the reservoir. Upon infection, RNA viruses infect as quasispecies (a population of heterogenous virions) [141,153,157-159]. Emergence of a zoonotic virus within a naive, nonreservoir host species may follow a bottleneck where only a few genotypes survive, and even these may require additional genetic changes within the viral population for successful transmission and adaptation to the new host species (e.g., by suppressing innate immunity as discussed above) $[2,6,160,161]$.

Examples of genetic mutations in viruses harbored by wildlife reservoirs that emerge and play a role in promoting reservoir-to-human and sustained human-to-human transmission are few but often involve the binding and/or entry of the virus to host cells, enhanced replicative ability in the new hosts, and/or suppression of innate immunity. Mutations enhancing reservoir-to-human transmission were reported in the first SARS-CoV spillover, where mutations in the virus's spike protein increased the protein's binding affinity to angiotensin converting enzyme 2 (ACE2) receptor of either the intermediary host, Asian palm civets (Paradoxurus hermaphroditus) or humans [162]. Mutations occurring after initial spillover of EBOV from its reservoir host into humans were observed in the 2013 West Africa outbreak, where a mutation in the virus's host cell-binding glycoprotein resulted in increased infectivity [163]. The mutation was primate specific, and ultimately, the mutation was associated with an increase in human mortality.

\section{A Look at Environmental Factors That Drive Spillover of Viruses in Bat and Rodent Populations}

From the first recognition of virus spillover from nature, scientists have endeavored to understand the drivers behind the emergence of new viruses. Factors such as climate change, land use change (i.e., logging, burning, agriculture), human expansion into habitat (i.e., recreation, farming), and land fragmentation (i.e., roads, buildings, towns) are some of the key drivers which seemingly alter wildlife populations and hence the balance of the virus in reservoir populations and drive spillover [2,164-166]. Each of these extrinsic pressures may impact the animal population by alteration of habitat (e.g., size, composition, fragmentation), resource availability (e.g., water, food, refuge), and /or community structure (e.g., species richness and diversity, population density and demographics) $[2,139,167-169]$. Any one of these, or a combination thereof, could influence host well-being and contact rates and thus may drive spillover of infectious agents into new host species. Complicating matters further, habitat preferences of abundant rodent species may be seasonally and interannually variable, resulting in probable temporal variation in interaction rates among reservoir and nonreservoir species [170]. Similarly, human activities may vary seasonally, altering their exposure and risk. Additionally, human cases may result from seasonal increases in rodent population densities and the movement of rodents into homes and barns during the colder seasons [2,171].

The ecological drivers of outbreaks by emerging and re-emerging zoonotic viruses are not well understood due to the challenges in designing controlled field studies to understand how each of these specific factors drive pathogen presence and prevalence in 
wild animal populations, and during an outbreak, surveillance is usually not conducted with this in mind. For example, during the outbreak of hantavirus pulmonary syndrome (HPS) in the southwestern USA in 1993 researchers surveyed animals in the vicinity of the trailers and homes of infected persons. This resulted in the identification of the deer mouse, as the reservoir of the causative agent, SNV. In nature, the prevalence of hantaviruses in rodent populations can vary from undetectable to $40 \%$ in the primary rodent reservoir $[137,140,168,172-174]$. A persistent conundrum of rodent-borne virus outbreaks that occur over large areas (e.g., southwestern USA, southern Argentina) is that cricetid and murid rodents live in relatively small habitats and conduct limited travel during their life span (usually $<$ two $\mathrm{km}^{2}$ ) [175]. This raises the question of whether all the mice in a particular outbreak zone respond similarly to an ecological or environmental change in situ or if viruses carried by the reservoir move across rodent populations as a traveling wave as one model suggests [176]. Retrospective analyses on the environmental characteristics of sites where people were infected with those at sites where people were not infected suggested that the areas impacted by El Niño-Southern Oscillation (ENSO) had a greater risk [177]. Nearly 20 years later, we have no concrete evidence, other than this, as to what drove the outbreak in the desert southwest. A second strong ENSO occurred in 1997-1998, and HPS rose 5-fold in the southwestern USA suggesting it as a clear factor [178].

It has been suggested that the most important drivers of spillover of bat-borne RNA viruses to humans is the anthropogenic encroachment into natural habitats of bats through urbanization and agriculture $[125,179,180]$. For example, anthropogenic deforestation as well as climate anomalies are proposed to have played a role in the outbreak of NiV. Large forest areas were burnt producing extensive haze, which drove the bats to follow an irregular migration. The area was also undergoing a severe drought caused by an ENSO event. These two factors combined drove bats carrying the virus to move into areas where pig barns were located, thereby transmitting NiV to pigs [181]. Outbreaks of filoviruses and henipaviruses correlate to birthing pulses of pups in the bat population $[64,125,182]$.

Clearly, reservoir population density and the prevalence of the virus in the population contribute to the probability of increased prevalence of the virus in its reservoir and the probability of spillover. In general; however, very little is known for many viruses in terms of how these viruses are maintained within their natural reservoirs, the normal prevalence of virus in wildlife, genetic variation within host and communities, and what drives increased spread in reservoir populations. In addition to natural history study of reservoir-virus populations in their native habitats, experimental field studies would help identify factors that change virus-host population dynamics.

\section{How Do Viruses Spillover from Bats or Rodents to Humans?}

The majority of spillover events from a wild rodent (Supplementary Table S1) or bat (Supplementary Table S2) species that results in infections of humans begin with direct or indirect contact (Figure 1) [7]. Direct contact between humans and rodent or bat reservoir hosts may occur through interactions such as touching animals shedding virus, activities associated with hunting and harvesting bushmeat, human consumption of bushmeat or contaminated food, or being bitten. Indirect contact with a virus from a rodent reservoir to a human mainly occurs through inhalation of aerosolized excreta from infected rodents [2]. Exposures to excreta have been associated with human activities such farming, camping, or outdoor military exercises in areas that are contaminated with the reservoir excreta. Similarly, inhalation of bat guano has been suggested as a potential route of exposure as suggested by human cases of Pteropine orthoreoviruses, coronaviruses, filoviruses and others that have occurred following visits to workplaces or caves where bats roost [183-185]. Many exposures are associated with housing or other buildings which rodents have invaded and occupied or have left excreta [186-191]. Direct or indirect contact may also occur via interactions with an intermediate spillover host (Figure 1). 


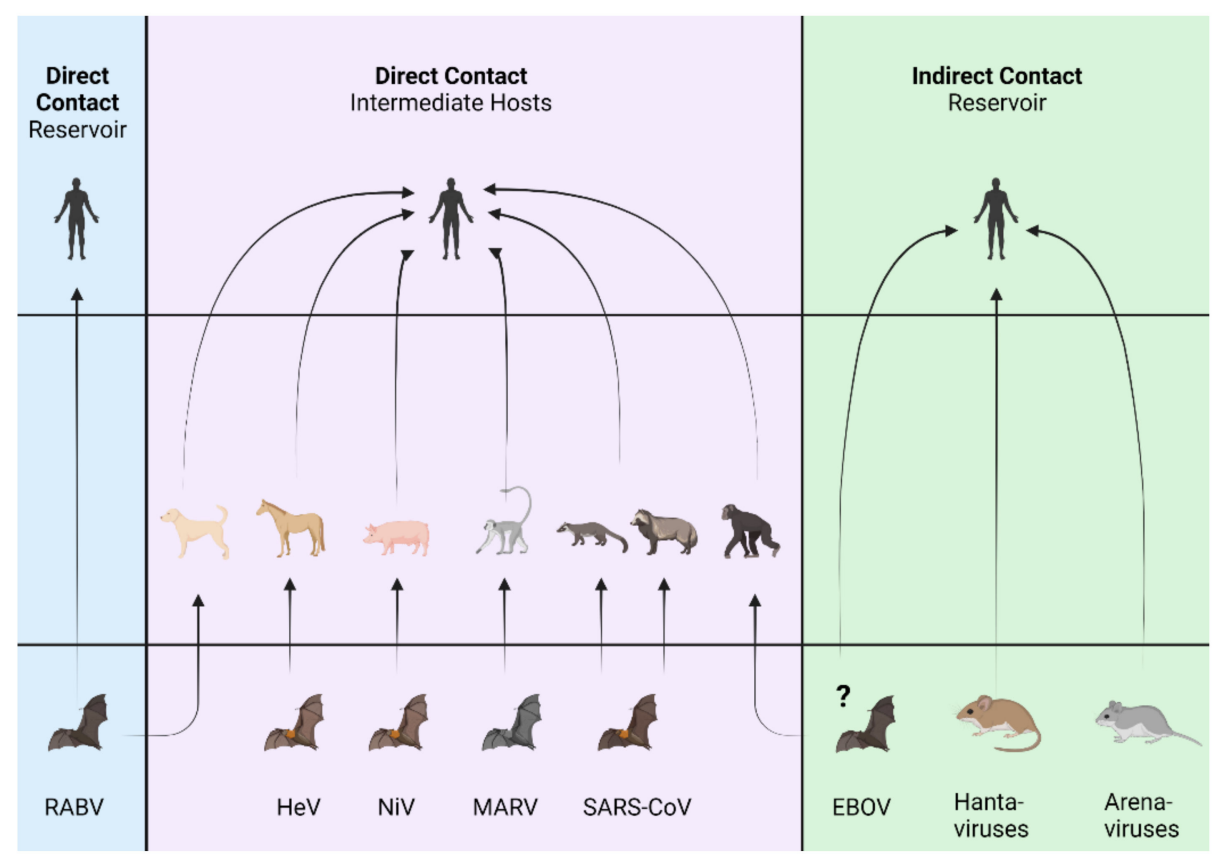

Figure 1. Major routes of spillover transmission of viruses harbored by bats and rodents. Three of the most common routes of exposure from bats or rodents to humans are depicted. As illustrated, more than one route may occur. Abbreviations: RABV, rabies viruses; $\mathrm{HeV}$, Hendra henipavirus; NiV, Nipah hendravirus; MARV, Marburg marburgvirus; SARS-CoV, severe acute respiratory syndrome coronavirus; EBOV, Ebolavirus species.

In the following, we briefly review the above scenarios of spillover that resulted in human cases of disease and characteristics of these events.

\subsection{Spillover Associated with Direct Animal Reservoir Contact}

Rabies lyssavirus, genus Lyssavirus, was the first bat-borne virus discovered, which in retrospect is unsurprising because $50 \%$ of the currently known viruses carried by bats are rhabdoviruses [19,192]. The first reported outbreak of rabies happened in 1929 in Trinidad when 17 fatal human cases were reported along with a similar disease in nearby cattle [32]. Dr. Pawan, the island's bacteriologist, found that rabies virus was transmitted from the bite of vampire bats to humans and cattle [32]. In the subsequent decade, Pawan further showed that insectivorous and frugivorous bats can harbor the virus as well [192]. Later in the United States, in addition to insectivorous bats, raccoons, skunks, and foxes were identified as additional reservoirs of rabies virus variants [193]. According to the WHO, there are approximately 59,000 human deaths from rabies in over 150 countries each year. Currently, $99 \%$ of all rabies cases comes from one intermediate host, dogs, through bites. In the US, rabies in dogs has been eradicated, and hence while the cases are low, rabies cases originate in bats, coyotes, raccoons, and skunks [194]. In addition to bites from rabies-infected animals, other animal bites are also associated with human cases of disease for several additional viruses [195-197].

Human cases of infection have been associated with consumption of their reservoirs for both bats and rodents. In certain areas, eating rodent bushmeat is considered a delicacy; therefore, human transmission can also occur by exposure to their bodily fluids (e.g., viremia in blood [64,197]) during hunting and food preparation [198,199]. Hence, it is not clear whether the consumption or the hunting was the major risk factor. Several cases of LASV have been associated with the capture and consumption of rodents [199].

\subsection{Spillover Associated with Direct Contact: Intermediate Hosts}

Some outbreaks in humans involving paramyxoviruses, coronaviruses, and filoviruses have occurred through contact with an intermediate host that acts as an amplifier 
host [179,200-203]. For example, palm civets and raccoon dogs (Nyctereutes procyonoides) from live markets may have played a crucial role in outbreaks of human diseases such as those caused by SARS-CoV $[202,204]$. Since coronaviruses in nature were very poorly sampled until the 2002-2003 SARS outbreak, there is no data that definitively shows whether direct or indirect transmission is more plausible [205]. The bat reservoir for SARS-CoV-2 has yet to be identified and an intermediate host has yet to be confirmed. In both instances, it has been suggested that a spillover occurred from a bat to an animal sold for human consumption in a live wildlife market [14,202]. In the case of MERS-CoV, research supports that spillover occurred from bats to dromedary camels, and camels transmit the virus to humans presumably through contact with nasal discharge [203,206-208].

MARV emerged in 1967 in Marburg and Frankfurt, Germany, as well as in Belgrade, Serbia, when 31 cases were reported of an unknown disease to which seven patients succumbed [209]. Epidemiological evaluation of the three outbreaks reported that those infected were working with vervet monkeys (Chlorocebus pygerythrus) that were imported from Uganda $[210,211]$. The search for the reservoir of MARV was a lengthy process, and in 2009 the putative reservoir was identified through molecular detection methods as the Egyptian rousette bat [212-214].

In September 1976, Zaire ebolavirus (ZEBOV) emerged in Zaire (now the Democratic Republic of Congo) and resulted in 318 cases with a mortality rate of $88 \%$ [215]. The first case occurred in a village near the Ebola River in Zaire. The man was an instructor at the Mission School, who, while traveling, purchased fresh and smoked antelope and monkey meat but only ate the antelope [215]. Outbreaks of EBOV occurred throughout Central and Western Africa in 1994 and 2000, and the largest outbreak occurred during 2013-2016 with sporadic outbreaks continuing. Extensive searches have been conducted to identify the reservoir, but it remains elusive $[216,217]$. Bats have been proposed to harbor the viruses but have not been proven to be the reservoir [34,37]. While the reservoir for the virus has yet to be identified, numerous outbreaks have occurred following humans handling animals such as primates (chimpanzees and gorillas) and antelopes (duikers) and their carcasses [218-220]. The presence of EBOV in a number of human bodily fluids enables very efficient person-to-person transmission [221].

There are two species of the Henipavirus associated with outbreaks of human disease, $\mathrm{HeV}$ and $\mathrm{NiV}$; these viruses are carried by multiple species of the bats commonly referred to as flying foxes (Pteropus spp.) [222-225]. HeV first emerged in Brisbane, Australia in 1994 when two human and 21 horse cases of an unidentified respiratory disease were reported, resulting in one human fatality and 14 horses being euthanized [200,201]. Since the initial outbreak, cases have been reported in Australia from interactions of humans with horses infected with the virus [226-228]. Although transmission of $\mathrm{HeV}$ from flying foxes to horses has yet to be demonstrated, it is hypothesized that transmission occurs when horses encounter urine from infected bats [229,230].

The first outbreak of NiV occurred in Malaysia during 1998 in pigs and humans, with 265 human cases (105 fatal) and the culling of nearly one million pigs [231,232]. The earlier outbreak of $\mathrm{HeV}$ suggested bats as a reservoir, and ultimately, seroprevalence surveys of bats showed that multiple species of bats had neutralizing antibodies to $\mathrm{NiV}$, and the virus was isolated from the urine collected from island flying foxes [233-235]. Spillover of NiV to pigs is thought to occur when pigs consume fruits that have been partially eaten by bats or via exposure to the excreta of infected bats [180]. In addition to contact with pigs, bat-to-human spillover is thought to occur through the consumption of date palm sap that has been contaminated with $\mathrm{NiV}$ from bat excreta [236]. Outbreaks of NiV with $40-70 \%$ fatality have since been reported in Bangladesh, India, and the Philippines [237-239]. Significantly, in Bangladesh and India, epidemiological evidence also indicates human-tohuman transmission through close contact. 


\subsection{Spillover Associated with Indirect Animal Reservoir Contact}

Epidemiological evidence suggests the indirect mode of transmission (aerosolized excreta) from rodents or bats to humans is similar for many zoonotic viruses. The literature supports indirect contact via inhalation of rodent excrement or direct contact with rodents such as rodent bites (discussed above) as the main routes of transmission to humans [2]. These exposures occur during certain types of human activities that are often in rural areas or in the natural environment or habitat of the reservoir. We will highlight seminal examples of specific human activities associated with outbreaks in human populations.

\subsubsection{The Role of Agriculture}

In South America, human cases of HPS, Argentine hemorrhagic fever (AHF), and Bolivian hemorrhagic fever (BHF) have been associated with agricultural activities. In the following we briefly discuss two notable outbreaks of arenaviruses associated with agricultural activity. Seven species of arenaviruses are known to cause hemorrhagic fever in humans in South America and Africa, presumably through the inhalation of aerosolized infectious excreta [240-242].

After its isolation in 1959, JUNV was the second arenavirus (following LCMV in 1933 in the USA) recognized to cause human illness, AHF [243,244]. The rodent reservoirs of JUNV, Calomys musculinus (dry lands vesper mouse) and C. laucha (small vesper mouse), are endemic to the Humid Pampas, a farming region in central east Argentina [245]. C. musculinus is believed to be the primary reservoir of JUNV, although antibody to the virus is also detected in C. laucha [245]. Rodent population density is positively correlated with JUNV seroprevalence. From these field studies of the reservoir, the main route of transmission is likely horizontal (fewer infections of juveniles and subadults and there is higher prevalence among males). The emergence of AHF is hypothesized to have occurred due to intensive deforestation and agriculture practices that promoted contact between humans and the rodent reservoirs. Since the first recognition of AHF in 1958, annual epidemics have been reported ranging from several hundred to 3500 cases, with most cases occurring between April and July (late fall and early winter) [244,246]. These outbreaks coincide with the corn harvesting season, which is thought to cause an increase in rodent population densities and to promote human-rodent contact. In fact, AHF mainly affects male rural workers.

Around the same time as JUNV was recognized, human outbreaks of MACV associated with Bolivian hemorrhagic fever (BHF) were reported in Bolivia [247]. The reservoir host of MACV is C. callous [248]. Outbreaks of BHF emerged in Beni Department, Bolivia during 1959, following political instability that led families living in rural areas to rapidly transition to subsistence agriculture [247]. It was reported that an increase in the use of DDT on crops for insect control coupled with abnormally low rainfall led to a decline in cats, resulting in an increase in rodent numbers. After 1959, there were multiple outbreaks in rural communities in Bolivia, which continued until 1964 with the implementation of rodent control measures (mouse traps and poisoning with zinc phosphide) [249]. Rodent control programs developed in San Joaquín during the outbreak of BHF in 1962 killed ca. 3000 C. callosus in a span of 4 months, demonstrating that this rodent can acquire high population densities around human habitations. During 18 months of research in Beni, Bolivia cases of BHF were reported in every month of the year, with a distinct increase from January to May a period of intense agricultural activity (rainy season) [247]. It was not until 1963 that MACV was isolated from the spleen of a patient who succumbed to disease [54]. Since its emergence, there have been sporadic outbreaks of BHF which have been related to agricultural occupational exposure. Cases are highest between April and July, which are the late rainy and early dry seasons, as C. callosus invades homes during the rainy seasons. However, only a handful of cases have occurred since the 1960's. In 2007-2008, an outbreak of five cases was reported among farmers in Bolivia [250]. 


\subsubsection{The Role of Caves, Rural Workplaces, and Homes}

After the first cases of MARV through direct contact with nonhuman primates, several other large outbreaks occurred throughout central and southern Africa; however, in contrast to the interaction with an intermediate nonhuman primate host discussed above, these cases were associated with patients visiting caves [251-253].

The first human cases of Sudan ebolavirus (SUDV) likely originated in a cotton factory in Nudar, Sudan in June 1976. In the five months that followed, 284 cases were reported with a mortality rate of $53 \%$. It is suggested that exposure occurred via excreta from bats roosting in this factory [254].

Cases of Lassa fever were recognized in the 1950s; however, the virus causing the illness, LASV, was not identified until 1969 when three nurses died from it in a mission hospital in Nigeria $[255,256]$. Many of the early outbreaks were localized within hospital wards, where nurses and doctors became exposed to patient bodily fluids [257-259]. Now, nosocomial infections are uncommon, and human transmission occurs mainly in village homes through direct contact with rodents or indirectly by consumption of contaminated food products, exposure to surfaces contaminated with rodent excreta, or inhalation of aerosolized virus [260]. Additionally, several cases have been recognized to be imported from individuals traveling from West Africa [261,262]. In West African villages where LASV is endemic, homes are usually devoid of food storage spaces such as cabinets (cupboards), so food is stored in plastic buckets or large flour bags on the ground or hung from ceilings or walls [263]. During the dry season (January-March) when there are limited food resources, $M$. natalensis tends to aggregate in homes in search for food [136]. These rodents excrete virus in their urine; therefore, an infected rodent can indirectly transmit the virus by urinating on food products [150]. More recently, the African wood mouse, Hylomyscus pamfi, in Nigeria and Guinea multimammate mouse, Mastomys erythroleucus, in both Nigeria and Guinea were recognized as additional hosts [264].

In the first outbreak of SNV in the summer of 1993 through 1995 in the Four Corners states of the southwestern USA, $69 \%$ of the hantavirus pulmonary syndrome (HPS) cases had exposures closely associated with peridomestic activities in homes that showed signs of rodent infestation [191]. A retrospective analysis of the outbreak of SNV during 1998-1999 noted that most HPS case patients reported indoor exposure to deer mice [178]. In the fall of 2012, a cluster of cases occurred in Yosemite in deer mice infested tent cabins in Curry Village [265]. Similar observations were made in outbreaks in Paraguay, while in Argentina most cases over a 13-year period were associated with agriculture [266], although there are reports suggesting peridomestic exposure [267].

\subsubsection{The Role of War}

The first recorded outbreak of hemorrhagic fever with renal syndrome (HFRS) associated with the hantavirus, HTNV occurred in soldiers during the Korean War in the early 1950 's and probably resulted from outdoor activities such as sleeping in tents and performing military exercises [268]. Similarly, cases of HFRS occurred in soldiers during the war in Bosnia [269] and in military training exercises of USA soldiers in Germany [270]. As noted in ecological surveillances of military sites in Korea [271,272], reservoir mice harboring hantaviruses are common in training areas with mortar ranges and troop maneuver/ assembly areas and pose a threat for exposure.

\subsubsection{Person to Person Transmission following Spillover}

Most human infections with hantaviruses and arenaviruses are associated with indirect exposure of rodent excreta. However, viruses in each genus have had suspected or documented cases of person-to-person transmission. In one report of illness from MACV, a 20-year-old female nursing student living in Cochabamba, Bolivia became ill following travel to her hometown in Fortaleza in Beni Department in December 1970 [273]. Upon return to Cochabamba, she was hospitalized and died January 28. Subsequently, five individuals who had direct contact with her in the hospital became ill and all died, including 
her father, nurses, and the pathologist who conducted her autopsy. More recently in 2008, a case of hemorrhagic fever caused by Lujo mammarenavirus involved a 36-year-old female travel agent who worked on a peri-urban farm near Lusaka, Zambia. Following illness, she was flown to Johannesburg, South Africa to be treated at a private hospital. There, four healthcare workers were exposed and became ill and three died [274]. Among the hantaviruses, there have been documented cases of person-to-person transmission only for the South American Andes orthohantavirus (ANDV) which have occurred in Argentina and Chile [267,275-279]. In 1996, the first human-to-human outbreak of ANDV was reported in southwest Argentina among 18 people [267]. The outbreak began on 22 September 1996 and lasted until 5 December 1996. The index case was a 41-year-old male who lived in the rural town El Bolsón. Twenty days after he became ill, his doctor became ill, followed by his 70-year-old mother a day later. Subsequently, several cases were reported from small household clusters, nosocomial infections, and from a car trip to the funeral of the 70-year-old mother. No evidence of nosocomial infections has been reported in Chile where ANDV is endemic [280]. However, transmission occurs mainly through household contacts and risk is especially high among sexual partners [278].

\section{Conclusions}

The number of novel or reemerging RNA viruses which cause infections in humans increases each year. While most of these zoonotic infections do not lead to a pandemic, the global public health burden of all combined infections is high. The 2002-2003 SARS$\mathrm{CoV}$ epidemic resulted in more than $\$ 40$ billion in losses despite causing fewer than 1000 deaths [281]. Predicting the next outbreak, epidemic or pandemic caused by an RNA virus will remain an on-going challenge for the foreseeable future. Predictive models will require a deep understanding of the intrinsic and extrinsic drivers of virus spillover in their native habitat and of how these viruses are maintained in their native reservoir. Whether a virus can persist for the lifetime of a reservoir host or can be cleared, the mechanisms that drive these outcomes is an area in need of expanded investigation, as there is a lack of literature for many reservoir species and viruses in this regard. Experimental animal reservoir models are essential for understanding these host-virus dynamics, and even conservative efforts to expand the taxonomic diversity of experimental models would prove worthwhile. Alternative rodent and bat experimental models of infection have provided important information as highlighted herein. In addition to expanding reservoir models, well-designed, targeted, empirical surveillance studies that incorporate immunological and pathological examinations may provide crucial information about the effect of natural infections. The principal challenges of field studies are largely technical; for example, identification of specific stages of infection of viruses in animals in nature while in the field in is unlikely, and the ability to isolate or detect virus in a persistent infection in the laboratory may be difficult if below the limit of detection, requiring more samples than in standard, controlled laboratory studies. Metagenomic approaches have improved in recent years and may eventually overcome technical limitations of detecting virus in field-sampled, persistently infected reservoirs. However, integration and interpretation of this information with immune response and pathology specific to the virus of interest will be challenging, as many animals collected in the field harbor other pathogens. Hence, this underscores the need to establish laboratory colonies of the natural reservoirs to benefit understanding. The difficulties of establishing alternative, reservoir models are numerous and challenging, but important for advancement of understanding biological mechanisms.

In addition to the natural reservoirs, intermediate spillover hosts (e.g., agricultural livestock and wildlife species that are kept as pets or taken for food consumption) play an important role in the transmission network of viruses to humans. As such, intermediate hosts acting as a bridge between natural reservoirs and humans warrants greater attention for advancing our understanding of virus transmission and maintenance from these hosts. In addition to surveillance of bats, efforts need to focus on intermediate hosts as many bat viruses' transmission to humans relies on these amplifier hosts. Metagenomic surveillance 
of potential intermediate hosts would provide valuable information on circulating and newly introduced viruses. Maintaining such samples in tissue biorepositories for wildlife specimens in museums is critical for retrospective analyses.

In areas where reservoirs and intermediate hosts are known, control measures should be used to keep these reservoirs in check, such as preventing bats and rodents from contaminating food sources. Controlling the further spread of outbreaks is an important aspect of study to prevent isolated outbreaks from progressing into epidemics or pandemics. One essential feature to controlling outbreaks is understanding transmission routes to limit further spread, e.g., aerosol with SARS-CoV-2 and exposure to infected bodily fluids in the case of EBOV. Controlling virus transmission during outbreak scenarios depends on virus population dynamics within the reservoir and intermediate hosts. Understanding virus populations and their variants within reservoir and intermediate hosts are important as inherent mutations and mutations acquired through transmission may lead to an increase in viral fitness, allowing for spillover and increased transmission, as seen in the case of SARS-CoV and the Asian palm civet. Additionally, host genetics needs to be investigated as host genetic background can influence infection outcome. Some host population members can have a higher likelihood of transmitting a virus compared to others within the same population (e.g., superspreaders). Efforts focused on virus surveillance, virus-host interaction, and virus population changes can be complicated as reservoirs, intermediate hosts, and the viruses they harbor lack necessary reagents for their study, so development of these reagents are essential. In summary, we have addressed (1) why zoonotic viruses reside in bat and rodent reservoirs, (2) environmental and ecological causes driving spillover, and (3) shared and unique characteristics of previous epizootic events. Further investigation of these topics is a long-term process that will take vigorous effort, but continuous investigation will provide an effective means to understand the relationship between spillover and emergence of bat- and rodent-borne RNA viruses in their hosts.

Supplementary Materials: The following are available online at https: / www.mdpi.com/article / 10.3390/v13081509/s1, Table S1: Examples of Outbreaks in Human Populations by RNA Viruses Harbored by Rodents, Table S2: Examples of Outbreaks in Human Populations by RNA Viruses Harbored by Bats. References [282-299] are cited in the Supplementary Materials.

Author Contributions: Conceptualization, C.B.J.; writing-original draft preparation, E.P.W., B.M.S.H. and C.B.J.; writing-review and editing, E.P.W., B.M.S.-H., M.K.T., J.L., A.V.N., Z.Y., J.H.N., J.V.C., R.D.O. and C.B.J.; funding acquisition, R.D.O. and C.B.J. All authors have read and agreed to the published version of the manuscript.

Funding: R.D.O. and C.B.J. acknowledge the support of the National Institutes of Health (NIH, USA) grant R01 AI103053. R.D.O. was partially supported by the Programa Nacional de Incentivo a los Investigadores (CONACYT, Paraguay). C.B.J. also acknowledges the support of the National Science Foundation (NSF, USA) award number 1516011.

Acknowledgments: We thank Linda Allen, Texas Tech University, Elizabeth Fitzpatrick, University of Tennessee Health Science Center and Greg Glass, University of Florida, for helpful suggestions in the review of this manuscript.

Conflicts of Interest: The authors declare no conflict of interest.

\section{References}

1. Taylor, L.H.; Latham, S.M.; Woolhouse, M.E. Risk factors for human disease emergence. Philos. Trans. R. Soc. Lond. B Biol. Sci. 2001, 356, 983-989. [CrossRef]

2. Childs, J.E.; Richt, J.A.; Mackenzie, J.S. Introduction: Conceptualizing and partitioning the emergence process of zoonotic viruses from wildlife to humans. Curr. Top. Microbiol. Immunol. 2007, 315, 1-31. [CrossRef]

3. Dobson, A.; Foufopoulos, J. Emerging infectious pathogens of wildlife. Philos. Trans. R. Soc. Lond. B Biol. Sci. 2001, 356, 1001-1012. [CrossRef]

4. Schultz, M. Photo Quiz. Emerg. Infect. Dis. 2008, 14, 1480-1481. [CrossRef]

5. Jones, K.E.; Patel, N.G.; Levy, M.A.; Storeygard, A.; Balk, D.; Gittleman, J.L.; Daszak, P. Global trends in emerging infectious diseases. Nature 2008, 451, 990-993. [CrossRef] [PubMed] 
6. Lloyd-Smith, J.O.; George, D.; Pepin, K.M.; Pitzer, V.E.; Pulliam, J.R.; Dobson, A.P.; Hudson, P.J.; Grenfell, B.T. Epidemic dynamics at the human-animal interface. Science 2009, 326, 1362-1367. [CrossRef] [PubMed]

7. Kreuder Johnson, C.; Hitchens, P.L.; Smiley Evans, T.; Goldstein, T.; Thomas, K.; Clements, A.; Joly, D.O.; Wolfe, N.D.; Daszak, P.; Karesh, W.B.; et al. Spillover and pandemic properties of zoonotic viruses with high host plasticity. Sci. Rep. 2015, 5, 14830. [CrossRef]

8. Olival, K.J.; Hosseini, P.R.; Zambrana-Torrelio, C.; Ross, N.; Bogich, T.L.; Daszak, P. Host and viral traits predict zoonotic spillover from mammals. Nature 2017, 546, 646-650. [CrossRef]

9. Woolhouse, M.E.J.; Adair, K.; Brierley, L. RNA Viruses: A case study of the biology of emerging infectious diseases. Microbiol. Spectr. 2013, 1. [CrossRef]

10. Woolhouse, M.E.J.; Brierley, L. Epidemiological characteristics of human-infective RNA viruses. Sci. Data 2018, 5, 180017. [CrossRef]

11. Morens, D.M.; Taubenberger, J.K.; Harvey, H.A.; Memoli, M.J. The 1918 influenza pandemic: Lessons for 2009 and the future. Crit. Care Med. 2010, 38, e10-e20. [CrossRef]

12. Hahn, B.H.; Shaw, G.M.; De Cock, K.M.; Sharp, P.M. AIDS as a zoonosis: Scientific and public health implications. Science 2000, 287, 607-614. [CrossRef]

13. Pybus, O.G.; Theze, J. Hepacivirus cross-species transmission and the origins of the hepatitis C virus. Curr. Opin. Virol. 2016, 16, 1-7. [CrossRef]

14. Zhou, P.; Yang, X.-L.; Wang, X.-G.; Hu, B.; Zhang, L.; Zhang, W.; Si, H.-R.; Zhu, Y.; Li, B.; Huang, C.-L.; et al. A pneumonia outbreak associated with a new coronavirus of probable bat origin. Nature 2020, 579, 270-273. [CrossRef]

15. Paraskevis, D.; Kostaki, E.G.; Magiorkinis, G.; Panayiotakopoulos, G.; Sourvinos, G.; Tsiodras, S. Full-genome evolutionary analysis of the novel corona virus (2019-nCoV) rejects the hypothesis of emergence as a result of a recent recombination event. Infect. Genet. Evol. 2020, 79, 104212. [CrossRef]

16. Hedges, S.B.; Dudley, J.; Kumar, S. TimeTree: A public knowledge-base of divergence times among organisms. Bioinformatics 2006, 22, 2971-2972. [CrossRef]

17. Hedges, S.B.; Marin, J.; Suleski, M.; Paymer, M.; Kumar, S. Tree of life reveals clock-like speciation and diversification. Mol. Biol. Evol. 2015, 32, 835-845. [CrossRef]

18. Carleton, M.D.; Musser, G.G. Order Rodentia. In Mammal Species of the World; A Taxonomic and Geographic Reference; Wilson, D.E., Reeder, D.M., Eds.; John Hopkins Press: Baltimore, MD, USA, 2005; Volume 2, pp. 745-1532.

19. Mollentze, N.; Streicker, D.G. Viral zoonotic risk is homogenous among taxonomic orders of mammalian and avian reservoir hosts. Proc. Natl. Acad. Sci. USA 2020, 117, 9423-9430. [CrossRef]

20. Burgin, C.J.; Colella, J.P.; Kahn, P.L.; Upham, N.S. How many species of mammals are there? J. Mammal. 2018, 99, 1-14. [CrossRef]

21. Calisher, C.H.; Childs, J.E.; Field, H.E.; Holmes, K.V.; Schountz, T. Bats: Important reservoir hosts of emerging viruses. Clin. Microbiol. Rev. 2006, 19, 531-545. [CrossRef]

22. Chen, L.; Liu, B.; Yang, J.; Jin, Q. DBatVir: The database of bat-associated viruses. Database 2014, 2014. [CrossRef]

23. Dobson, A.P. Virology. What links bats to emerging infectious diseases? Science 2005, 310, 628-629. [CrossRef] [PubMed]

24. Li, W.; Shi, Z.; Yu, M.; Ren, W.; Smith, C.; Epstein, J.H.; Wang, H.; Crameri, G.; Hu, Z.; Zhang, H.; et al. Bats are natural reservoirs of SARS-like coronaviruses. Science 2005, 310, 676-679. [CrossRef]

25. Hayman, D.T.S. Bats as viral reservoirs. Annu. Rev. Virol. 2016, 3, 77-99. [CrossRef]

26. Banyard, A.C.; Hayman, D.; Johnson, N.; McElhinney, L.; Fooks, A.R. Chapter 12-Bats and Lyssaviruses. In Advances in Virus Research; Jackson, A.C., Ed.; Academic Press: London, UK, 2011; Volume 79, pp. 239-289.

27. Fischer, K.; Pinho Dos Reis, V.; Balkema-Buschmann, A. Bat astroviruses: Towards understanding the transmission dynamics of a neglected virus family. Viruses 2017, 9, 34. [CrossRef]

28. Ge, X.; Li, J.; Peng, C.; Wu, L.; Yang, X.; Wu, Y.; Zhang, Y.; Shi, Z. Genetic diversity of novel circular ssDNA viruses in bats in China. J. Gen. Virol. 2011, 92, 2646-2653. [CrossRef]

29. Maeda, K.; Hondo, E.; Terakawa, J.; Kiso, Y.; Nakaichi, N.; Endoh, D.; Sakai, K.; Morikawa, S.; Mizutani, T. Isolation of novel adenovirus from fruit bat (Pteropus dasymallus yayeyamae). Emerg. Infect. Dis. 2008, 14, 347-349. [CrossRef]

30. Lau, S.K.P.; Ahmed, S.S.; Tsoi, H.W.; Yeung, H.C.; Li, K.S.M.; Fan, R.Y.Y.; Zhao, P.S.H.; Lau, C.C.C.; Lam, C.S.F.; Choi, K.K.F.; et al. Bats host diverse parvoviruses as possible origin of mammalian dependoparvoviruses and source for bat-swine interspecies transmission. J. Gen. Virol. 2017, 98, 3046-3059. [CrossRef]

31. Baker, K.S.; Murcia, P.R. Poxviruses in bats ... so what? Viruses. 2014, 6, 1564-1577. [CrossRef] [PubMed]

32. Hurst, E.W.; Pawan, J.L. An outbreak of rabies in Trinidad without a history of bites and with the symptoms of acute ascending myelitis. Lancet 1931, 218, 622-628. [CrossRef]

33. Schountz, T. Immunology of bats and their viruses: Challenges and opportunities. Viruses 2014, 6, 4880-4901. [CrossRef]

34. Leroy, E.M.; Kumulungui, B.; Pourrut, X.; Rouquet, P.; Hassanin, A.; Yaba, P.; Délicat, A.; Paweska, J.T.; Gonzalez, J.-P.; Swanepoel, R. Fruit bats as reservoirs of Ebola virus. Nature 2005, 438, 575-576. [CrossRef] [PubMed]

35. Swanepoel, R.; Leman, P.A.; Burt, F.J.; Zachariades, N.A.; Braack, L.E.; Ksiazek, T.G.; Rollin, P.E.; Zaki, S.R.; Peters, C.J. Experimental inoculation of plants and animals with Ebola virus. Emerg. Infect. Dis. 1996, 2, 321-325. [CrossRef] [PubMed]

36. Leendertz, S.A.; Gogarten, J.F.; Düx, A.; Calvignac-Spencer, S.; Leendertz, F.H. Assessing the evidence supporting fruit bats as the primary reservoirs for Ebola viruses. Ecohealth 2016, 13, 18-25. [CrossRef] 
37. Koch, L.K.; Cunze, S.; Kochmann, J.; Klimpel, S. Bats as putative Zaire ebolavirus reservoir hosts and their habitat suitability in Africa. Sci. Rep. 2020, 10. [CrossRef]

38. Brook, C.E.; Dobson, A.P. Bats as 'special' reservoirs for emerging zoonotic pathogens. Trends Microbiol. 2015, 23, 172-180. [CrossRef] [PubMed]

39. Schountz, T.; Baker, M.L.; Butler, J.; Munster, V. Immunological control of viral infections in bats and the emergence of viruses highly pathogenic to humans. Front. Immunol. 2017, 8, 1098. [CrossRef]

40. Letko, M.; Seifert, S.N.; Olival, K.J.; Plowright, R.K.; Munster, V.J. Bat-borne virus diversity, spillover and emergence. Nat. Rev. Microbiol. 2020, 18, 461-471. [CrossRef] [PubMed]

41. Han, B.A.; Schmidt, J.P.; Bowden, S.E.; Drake, J.M. Rodent reservoirs of future zoonotic diseases. Proc. Natl. Acad. Sci. USA 2015, 112, 7039-7044. [CrossRef]

42. Easterbrook, J.D.; Klein, S.L. Immunological mechanisms mediating Hantavirus persistence in rodent reservoirs. PLoS Pathog. 2008, 4, e1000172. [CrossRef] [PubMed]

43. Botten, J.; Mirowsky, K.; Kusewitt, D.; Ye, C.; Gottlieb, K.; Prescott, J.; Hjelle, B. Persistent Sin Nombre virus infection in the deer mouse (Peromyscus maniculatus) model: Sites of replication and strand-specific expression. J. Virol. 2003, 77, 1540-1550. [CrossRef]

44. Pavlovich, S.S.; Lovett, S.P.; Koroleva, G.; Guito, J.C.; Arnold, C.E.; Nagle, E.R.; Kulcsar, K.; Lee, A.; Thibaud-Nissen, F.; Hume, A.J.; et al. The Egyptian rousette genome reveals unexpected features of bat antiviral immunity. Cell 2018, 173, 1098.e18-1110.e18. [CrossRef]

45. Banerjee, A.; Baker, M.L.; Kulcsar, K.; Misra, V.; Plowright, R.; Mossman, K. Novel insights into immune systems of bats. Front. Immunol. 2020, 11, 26. [CrossRef]

46. Irving, A.T.; Ahn, M.; Goh, G.; Anderson, D.E.; Wang, L.F. Lessons from the host defences of bats, a unique viral reservoir. Nature 2021, 589, 363-370. [CrossRef] [PubMed]

47. Fooks, A.R.; Johnson, N.; Muller, T.; Vos, A.; Mansfield, K.; Hicks, D.; Nunez, A.; Freuling, C.; Neubert, L.; Kaipf, I.; et al. Detection of high levels of European bat lyssavirus type-1 viral RNA in the thyroid gland of experimentally-infected Eptesicus fuscus bats. Zoonoses Public Health 2009, 56, 270-277. [CrossRef]

48. Begeman, L.; GeurtsvanKessel, C.; Finke, S.; Freuling, C.M.; Koopmans, M.; Muller, T.; Ruigrok, T.J.H.; Kuiken, T. Comparative pathogenesis of rabies in bats and carnivores, and implications for spillover to humans. Lancet Infect. Dis. 2018, 18, e147-e159. [CrossRef]

49. Suu-Ire, R.; Begeman, L.; Banyard, A.C.; Breed, A.C.; Drosten, C.; Eggerbauer, E.; Freuling, C.M.; Gibson, L.; Goharriz, H.; Horton, D.L.; et al. Pathogenesis of bat rabies in a natural reservoir: Comparative susceptibility of the straw-colored fruit bat (Eidolon helvum) to three strains of Lagos bat virus. PLoS Negl. Trop. Dis. 2018, 12, e0006311. [CrossRef]

50. De Araujo, J.L.; Nascimento, E.M.; Dantas, A.F.; Galiza, G.J.; Pedroso, P.M.; Silva, M.L.; Riet-Correa, F. Rabies in the insectivorous Pallas's mastiff bat (Molossus molossus) in northeastern Brazil. J. Wildl. Dis. 2014, 50, 883-886. [CrossRef]

51. Cogswell-Hawkinson, A.; Bowen, R.; James, S.; Gardiner, D.; Calisher, C.H.; Adams, R.; Schountz, T. Tacaribe virus causes fatal infection of an ostensible reservoir host, the Jamaican fruit bat. J. Virol. 2012, 86, 5791-5799. [CrossRef]

52. Malmlov, A.; Seetahal, J.; Carrington, C.; Ramkisson, V.; Foster, J.; Miazgowicz, K.L.; Quackenbush, S.; Rovnak, J.; Negrete, O.; Munster, V.; et al. Serological evidence of arenavirus circulation among fruit bats in Trinidad. PLoS ONE 2017, 12, e0185308. [CrossRef]

53. Webb, P.A.; Justines, G.; Johnson, K.M. Infection of wild and laboratory animals with Machupo and Latino viruses. Bull. World Health Organ. 1975, 52, 493-499.

54. Johnson, K.M. Epidemiology of Machupo virus infection. 3. Significance of virological observations in man and animals. Am. J. Trop. Med. Hyg. 1965, 14, 816-818. [CrossRef]

55. Southern, P.J. Arenaviruses. In Fields Virology, 3rd ed.; Fields, B.N., Knipe, D.M., Howley, P.M., Chanock, R.M., Melnick, J.L., Monath, T.P., Roizman, R., Straus, S.E., Eds.; Lippincott-Raven Publishers: Philadelphia, PA, USA, 1996; pp. $1505-1519$.

56. Luis, A.D.; Douglass, R.J.; Hudson, P.J.; Mills, J.N.; Bjornstad, O.N. Sin Nombre hantavirus decreases survival of male deer mice. Oecologia 2012, 169, 431-439. [CrossRef]

57. Kallio, E.R.; Voutilainen, L.; Vapalahti, O.; Vaheri, A.; Henttonen, H.; Koskela, E.; Mappes, T. Endemic Hantavirus infection impairs the winter survival of its rodent host. Ecology 2007, 88, 1911-1916. [CrossRef]

58. Watanabe, S.; Masangkay, J.S.; Nagata, N.; Morikawa, S.; Mizutani, T.; Fukushi, S.; Alviola, P.; Omatsu, T.; Ueda, N.; Iha, K.; et al. Bat Coronaviruses and Experimental Infection of Bats, the Philippines. Emerg. Infect. Dis. 2010, 16, 1217-1223. [CrossRef]

59. Munster, V.J.; Adney, D.R.; van Doremalen, N.; Brown, V.R.; Miazgowicz, K.L.; Milne-Price, S.; Bushmaker, T.; Rosenke, R.; Scott, D.; Hawkinson, A.; et al. Replication and shedding of MERS-CoV in Jamaican fruit bats (Artibeus jamaicensis). Sci. Rep. 2016, 6, 21878. [CrossRef]

60. Amman, B.R.; Carroll, S.A.; Reed, Z.D.; Sealy, T.K.; Balinandi, S.; Swanepoel, R.; Kemp, A.; Erickson, B.R.; Comer, J.A.; Campbell, S.; et al. Seasonal pulses of Marburg virus circulation in juvenile rousettus aegyptiacus bats coincide with periods of increased risk of human infection. PLoS Pathog. 2012, 8. [CrossRef]

61. Amman, B.R.; Jones, M.E.B.; Sealy, T.K.; Uebelhoer, L.S.; Schuh, A.J.; Bird, B.H.; Coleman-McCray, J.D.; Martin, B.E.; Nichol, S.T.; Towner, J.S. Oral shedding of Marburg virus in experimentally infected Egyptian fruit bats (Rousettus aegyptiacus). J. Wildl. Dis. 2015, 51, 113-124. [CrossRef] 
62. Paweska, J.T.; Jansen van Vuren, P.; Fenton, K.A.; Graves, K.; Grobbelaar, A.A.; Moolla, N.; Leman, P.; Weyer, J.; Storm, N.; McCulloch, S.D.; et al. Lack of Marburg virus transmission from experimentally infected to susceptible in-contact Egyptian fruit bats. J. Infect. Dis. 2015, 212, S109-S118. [CrossRef] [PubMed]

63. Paweska, J.T.; Jansen van Vuren, P.; Masumu, J.; Leman, P.A.; Grobbelaar, A.A.; Birkhead, M.; Clift, S.; Swanepoel, R.; Kemp, A. Virological and serological findings in Rousettus aegyptiacus experimentally inoculated with vero cells-adapted hogan strain of Marburg virus. PLoS ONE 2012, 7, e45479. [CrossRef]

64. Schuh, A.J.; Amman, B.R.; Jones, M.E.B.; Sealy, T.K.; Uebelhoer, L.S.; Spengler, J.R.; Martin, B.E.; Coleman-Mccray, J.A.D.; Nichol, S.T.; Towner, J.S. Modelling filovirus maintenance in nature by experimental transmission of Marburg virus between Egyptian rousette bats. Nat. Commun. 2017, 8, 14446. [CrossRef] [PubMed]

65. Halpin, K.; Hyatt, A.D.; Fogarty, R.; Middleton, D.; Bingham, J.; Epstein, J.H.; Rahman, S.A.; Hughes, T.; Smith, C.; Field, H.E.; et al. Pteropid bats are confirmed as the reservoir hosts of henipaviruses: A comprehensive experimental study of virus transmission. Am. J. Trop. Med. Hyg. 2011, 85, 946-951. [CrossRef]

66. Middleton, D.J.; Morrissy, C.J.; van der Heide, B.M.; Russell, G.M.; Braun, M.A.; Westbury, H.A.; Halpin, K.; Daniels, P.W. Experimental Nipah virus infection in pteropid bats (Pteropus poliocephalus). J. Comp. Pathol. 2007, 136, 266-272. [CrossRef]

67. Woon, A.P.; Boyde, V.; Todd, S.; Smith, I.; Klein, K.; Woodhouse, I.B.; Riddell, S.; Crameri, G.; Bingham, J.; Wang, L.F.; et al. Acute experimental infection of bats and ferrets with Hendra virus: Insights into the early host response of the reservoir host and susceptible model species. PLoS Pathog. 2020, 16, e1008412. [CrossRef]

68. Amman, B.R.; Schuh, A.J.; Sealy, T.K.; Spengler, J.R.; Welch, S.R.; Kirejczyk, S.G.M.; Albariño, C.G.; Nichol, S.T.; Towner, J.S. Experimental infection of Egyptian rousette bats (Rousettus aegyptiacus) with Sosuga virus demonstrates potential transmission routes for a bat-borne human pathogenic paramyxovirus. PLoS Negl. Trop. Dis. 2020, 14, e0008092. [CrossRef]

69. O'Shea, T.J.; Cryan, P.M.; Cunningham, A.A.; Fooks, A.R.; Hayman, D.T.; Luis, A.D.; Peel, A.J.; Plowright, R.K.; Wood, J.L. Bat flight and zoonotic viruses. Emerg. Infect. Dis. 2014, 20, 741-745. [CrossRef]

70. Hanadhita, D.; Satyaningtijas, A.S.; Agungpriyono, S. Bats oxidative stress defense. J. Indones. Vet. Res. 2019, 3. [CrossRef]

71. Zhang, G.; Cowled, C.; Shi, Z.; Huang, Z.; Bishop-Lilly, K.A.; Fang, X.; Wynne, J.W.; Xiong, Z.; Baker, M.L.; Zhao, W.; et al. Comparative analysis of bat genomes provides insight into the evolution of flight and immunity. Science 2013, 339, 456-460. [CrossRef]

72. Xie, J.; Li, Y.; Shen, X.; Goh, G.; Zhu, Y.; Cui, J.; Wang, L.-F.; Shi, Z.-L.; Zhou, P. Dampened STING-dependent interferon activation in bats. Cell Host Microbe. 2018, 23, 297.e294-301.e294. [CrossRef] [PubMed]

73. Miller, M.R.; McMinn, R.J.; Misra, V.; Schountz, T.; Muller, M.A.; Kurth, A.; Munster, V.J. Broad and temperature independent replication potential of filoviruses on cells derived from Old and New world bat species. J. Infect. Dis. 2016, 214, S297-S302. [CrossRef]

74. Subudhi, S.; Rapin, N.; Misra, V. Immune system modulation and viral persistence in bats: Understanding viral spillover. Viruses 2019, 11, 192. [CrossRef]

75. Gorbunova, V.; Seluanov, A.; Kennedy, B.K. The world goes bats: Living longer and tolerating viruses. Cell Metab. 2020, 32, 31-43. [CrossRef]

76. Virgin, H.W.; Wherry, E.J.; Ahmed, R. Redefining chronic viral infection. Cell 2009, 138, 30-50. [CrossRef]

77. Schountz, T.; Prescott, J.; Cogswell, A.C.; Oko, L.; Mirowsky-Garcia, K.; Galvez, A.P.; Hjelle, B. Regulatory T cell-like responses in deer mice persistently infected with Sin Nombre virus. Proc. Nat. Acad. Sci. USA 2007, 104, 15496-15501. [CrossRef]

78. Zhou, X.; Ramachandran, S.; Mann, M.; Popkin, D. Role of Lymphocytic Choriomeningitis Virus (LCMV) in understanding viral immunology: Past, present and future. Viruses 2012, 4, 2650-2669. [CrossRef]

79. He, X.; Korytar, T.; Schatz, J.; Freuling, C.M.; Muller, T.; Kollner, B. Anti-lyssaviral activity of interferons kappa and omega from the serotine bat, Eptesicus serotinus. J. Virol. 2014, 88, 5444-5454. [CrossRef]

80. Banerjee, A.; Rapin, N.; Bollinger, T.; Misra, V. Lack of inflammatory gene expression in bats: A unique role for a transcription repressor. Sci. Rep. 2017, 7, 2232. [CrossRef]

81. Kuzmin, I.V.; Schwarz, T.M.; Ilinykh, P.A.; Jordan, I.; Ksiazek, T.G.; Sachidanandam, R.; Basler, C.F.; Bukreyev, A. Innate immune responses of bat and human cells to filoviruses: Commonalities and distinctions. J. Virol. 2017, 91. [CrossRef] [PubMed]

82. Zhou, P.; Tachedjian, M.; Wynne, J.W.; Boyd, V.; Cui, J.; Smith, I.; Cowled, C.; Ng, J.H.; Mok, L.; Michalski, W.P.; et al. Contraction of the type I IFN locus and unusual constitutive expression of IFN-alpha in bats. Proc. Natl. Acad. Sci. USA 2016, 113, $2696-2701$. [CrossRef] [PubMed]

83. Guito, J.C.; Prescott, J.B.; Arnold, C.E.; Amman, B.R.; Schuh, A.J.; Spengler, J.R.; Sealy, T.K.; Harmon, J.R.; Coleman-McCray, J.D.; Kulcsar, K.A.; et al. Asymptomatic infection of Marburg virus reservoir bats is explained by a strategy of immunoprotective disease tolerance. Curr. Biol. 2021, 31, 257.e5-270.e5. [CrossRef]

84. Janardhana, V.; Tachedjian, M.; Crameri, G.; Cowled, C.; Wang, L.F.; Baker, M.L. Cloning, expression and antiviral activity of IFNgamma from the Australian fruit bat, Pteropus alecto. Dev. Comp. Immunol. 2012, 36, 610-618. [CrossRef]

85. Virtue, E.R.; Marsh, G.A.; Baker, M.L.; Wang, L.F. Interferon production and signaling pathways are antagonized during henipavirus infection of fruit bat cell lines. PLoS ONE 2011, 6, e22488. [CrossRef] [PubMed]

86. Levine, J.R.; Prescott, J.; Brown, K.S.; Best, S.M.; Ebihara, H.; Feldmann, H. Antagonism of type I interferon responses by new world hantaviruses. J. Virol. 2010, 84, 11790-11801. [CrossRef]

87. Binder, F.; Lenk, M.; Weber, S.; Stoek, F.; Dill, V.; Reiche, S.; Riebe, R.; Wernike, K.; Hoffmann, D.; Ziegler, U.; et al. Common vole (Microtus arvalis) and bank vole (Myodes glareolus) derived permanent cell lines differ in their susceptibility and replication kinetics of animal and zoonotic viruses. J. Virol. Methods 2019, 274, 113729. [CrossRef] 
88. Verhelst, J.; Hulpiau, P.; Saelens, X. Mx Proteins: Antiviral gatekeepers that restrain the uninvited. Microbiol. Mol. Biol. Rev. 2013, 77, 551-566. [CrossRef] [PubMed]

89. Dubois, A.; Castel, G.; Murri, S.; Pulido, C.; Pons, J.B.; Benoit, L.; Loiseau, A.; Lakhdar, L.; Galan, M.; Marianneau, P.; et al. Bank vole immunoheterogeneity may limit Nephropatia Epidemica emergence in a French non-endemic region. Parasitology 2018, 145, 393-407. [CrossRef]

90. Dubois, A.; Galan, M.; Cosson, J.F.; Gauffre, B.; Henttonen, H.; Niemimaa, J.; Razzauti, M.; Voutilainen, L.; Vitalis, R.; Guivier, E.; et al. Microevolution of bank voles (Myodes glareolus) at neutral and immune-related genes during multiannual dynamic cycles: Consequences for Puumala hantavirus epidemiology. Infect. Genet. Evol. 2017, 49, 318-329. [CrossRef]

91. Fuchs, J.; Holzer, M.; Schilling, M.; Patzina, C.; Schoen, A.; Hoenen, T.; Zimmer, G.; Marz, M.; Weber, F.; Muller, M.A.; et al. Evolution and antiviral specificities of Interferon-Induced Mx proteins of bats against Ebola, Influenza, and other RNA viruses. J. Virol. 2017, 91. [CrossRef]

92. Bratsch, S.; Wertz, N.; Chaloner, K.; Kunz, T.H.; Butler, J.E. The little brown bat, M. lucifugus, displays a highly diverse V H, D H and J H repertoire but little evidence of somatic hypermutation. Dev. Comp. Immunol. 2011, 35, 421-430. [CrossRef]

93. Terajima, M.; Ennis, F.A. T cells and pathogenesis of hantavirus cardiopulmonary syndrome and hemorrhagic fever with renal syndrome. Viruses 2011, 3, 1059-1073. [CrossRef]

94. Kruger, D.H.; Schonrich, G.; Klempa, B. Human pathogenic hantaviruses and prevention of infection. Hum. Vaccines 2011, 7, 685-693. [CrossRef]

95. Yasuda, S.P.; Shimizu, K.; Koma, T.; Hoa, N.T.; Le, M.Q.; Wei, Z.; Muthusinghe, D.S.; Lokupathirage, S.M.W.; Hasebe, F.; Yamashiro, T.; et al. Immunological responses to Seoul Orthohantavirus in experimentally and naturally infected Brown rats (Rattus norvegicus). Viruses 2021, 13, 665. [CrossRef]

96. Dohmae, K.; Okabe, M.; Nishimune, Y. Experimental transmission of hantavirus infection in laboratory rats. J. Infect. Dis. 1994, 170, 1589-1592. [CrossRef]

97. Araki, K.; Yoshimatsu, K.; Lee, B.H.; Kariwa, H.; Takashima, I.; Arikawa, J. Hantavirus-specific CD8(+)-T-cell responses in newborn mice persistently infected with Hantaan virus. J. Virol. 2003, 77, 8408-8417. [CrossRef]

98. Taruishi, M.; Yoshimatsu, K.; Araki, K.; Okumura, M.; Nakamura, I.; Kajino, K.; Arikawa, J. Analysis of the immune response of Hantaan virus nucleocapsid protein-specific CD8+ T cells in mice. Virology 2007, 365, 292-301. [CrossRef]

99. Easterbrook, J.D.; Klein, S.L. Seoul virus enhances regulatory and reduces proinflammatory responses in male Norway rats. J. Med. Virol. 2008, 80, 1308-1318. [CrossRef]

100. Au, R.Y.; Jedlicka, A.E.; Li, W.; Pekosz, A.; Klein, S.L. Seoul virus suppresses NF-kB-mediated inflammatory responses of antigen presenting cells from Norway rats. Virology 2010, 400, 115-127. [CrossRef]

101. Li, W.; Klein, S.L. Seoul virus-infected rat lung endothelial cells and alveolar macrophages differ in their ability to support virus replication and induce regulatory T cell phenotypes. J. Virol. 2012, 86, 11845-11855. [CrossRef]

102. Easterbrook, J.D.; Zink, M.C.; Klein, S.L. Regulatory T cells enhance persistence of the zoonotic pathogen Seoul virus in its reservoir host. Proc. Natl. Acad. Sci. USA 2007, 104, 15502-15507. [CrossRef]

103. Schountz, T.; Acuna-Retamar, M.; Feinstein, S.; Prescott, J.; Torres-Perez, F.; Podell, B.; Peters, S.; Ye, C.; Black, W.C.T.; Hjelle, B. Kinetics of immune responses in deer mice experimentally infected with Sin Nombre virus. J. Virol. 2012, 86, 10015-10027. [CrossRef]

104. Saeidi, A.; Zandi, K.; Cheok, Y.Y.; Saeidi, H.; Wong, W.F.; Lee, C.Y.Q.; Cheong, H.C.; Yong, Y.K.; Larsson, M.; Shankar, E.M. T-Cell exhaustion in chronic infections: Reversing the state of exhaustion and reinvigorating optimal protective immune responses. Front. Immunol. 2018, 9. [CrossRef]

105. McLane, L.M.; Abdel-Hakeem, M.S.; Wherry, E.J. CD8 T cell exhaustion during chronic viral infection and cancer. Annu. Rev. Immunol. 2019, 37, 457-495. [CrossRef]

106. Sandu, I.; Cerletti, D.; Oetiker, N.; Borsa, M.; Wagen, F.; Spadafora, I.; Welten, S.P.M.; Stolz, U.; Oxenius, A.; Claassen, M. Landscape of exhausted virus-specific CD8 T cells in chronic LCMV Infection. Cell Rep. 2020, 32, 108078. [CrossRef]

107. Zajac, A.J.; Blattman, J.N.; Murali-Krishna, K.; Sourdive, D.J.D.; Suresh, M.; Altman, J.D.; Ahmed, R. Viral Immune Evasion due to persistence of activated T cells without effector function. J. Exp. Med. 1998, 188, 2205-2213. [CrossRef]

108. Wherry, E.J.; Blattman, J.N.; Murali-Krishna, K.; van der Most, R.; Ahmed, R. Viral persistence alters CD8 T-cell immunodominance and tissue distribution and results in distinct stages of functional impairment. J. Virol. 2003, 77, 4911-4927. [CrossRef]

109. Wherry, E.J.; Ha, S.; Kaech, S.M.; Haining, W.N.; Sarkar, S.; Kalia, V.; Subramaniam, S.; Blattman, J.N.; Barber, D.L.; Ahmed, R. Molecular signature of CD8+T cell exhaustionduring chronic viral infection. Immunity 2007, 27, 670-684. [CrossRef]

110. Barber, D.L.; Wherry, E.J.; Masopust, D.; Zhu, B.; Allison, J.P.; Sharpe, A.H.; Freeman, G.J.; Ahmed, R. Restoring function in exhausted CD8 T cells during chronic viral infection. Nature 2006, 439, 682-687. [CrossRef]

111. Richter, K.; Agnellini, P.; Oxenius, A. On the role of the inhibitory receptor LAG-3 in acute and chronic LCMV infection. Int. Immunol. 2010, 22, 13-23. [CrossRef]

112. Gupta, P.K.; Godec, J.; Wolski, D.; Adland, E.; Yates, K.; Pauken, K.E.; Cosgrove, C.; Ledderose, C.; Junger, W.G.; Robson, S.C.; et al. CD39 expression identifies terminally exhausted CD8+ T cells. PLoS Pathog. 2015, 11, e1005177. [CrossRef]

113. Odorizzi, P.M.; Wherry, E.J. Inhibitory receptors on lymphocytes: Insights from infections. J. Immunol. 2012, 188, 2957-2965. [CrossRef] 
114. Yao, C.; Sun, H.-W.; Lacey, N.E.; Ji, Y.; Moseman, E.A.; Shih, H.-Y.; Heuston, E.F.; Kirby, M.; Anderson, S.; Cheng, J.; et al. Single-cell RNA-seq reveals TOX as a key regulator of CD8+ T cell persistence in chronic infection. Nat. Immunol. 2019, 20, 890-901. [CrossRef]

115. Blackburn, S.D.; Crawford, A.; Shin, H.; Polley, A.; Freeman, G.J.; Wherry, E.J. Tissue-specific differences in PD-1 and PD-L1 expression during chronic viral infection: Implications for CD8 T-cell exhaustion. J. Virol. 2010, 84, 2078-2089. [CrossRef]

116. Martínez Gómez, J.M.; Periasamy, P.; Dutertre, C.-A.; Irving, A.T.; Ng, J.H.J.; Crameri, G.; Baker, M.L.; Ginhoux, F.; Wang, L.-F.; Alonso, S. Phenotypic and functional characterization of the major lymphocyte populations in the fruit-eating bat Pteropus alecto. Sci. Rep. 2016, 6, 37796. [CrossRef]

117. Periasamy, P.; Hutchinson, P.E.; Chen, J.; Bonne, I.; Shahul Hameed, S.S.; Selvam, P.; Hey, Y.Y.; Fink, K.; Irving, A.T.; Dutertre, C.-A.; et al. Studies on B cells in the Fruit-Eating Black Flying Fox (Pteropus alecto). Front. Immunol. 2019, 10. [CrossRef]

118. Kunz, T.H. Roosting ecology of bats. In Ecology of Bats; Kunz, T.H., Ed.; Springer: Boston, MA, USA, 1982 ; pp. 1-55.

119. Leu, H. Miniopterus schreibersii. Animal Diversity Web. 2000. Available online: https://animaldiversity.org/accounts/ Miniopterus_schreibersii/ (accessed on 8 June 2021).

120. Esmailka, L. Nycteris thebaica. Animal Diversity Web. 2005. Available online: https://animaldiversity.org/accounts/Nycteris_ thebaica/ (accessed on 8 June 2021).

121. Schiefelbein, O. Rousettus amplexicaudatus. Animal Diversity Web. 2013. Available online: https://animaldiversity.org/ accounts/Rousettus_amplexicaudatus/ (accessed on 8 June 2021).

122. Ruiz, K. Eidolon helvum. Animal Diversity Web. 2002. Available online: https://animaldiversity.org/accounts/Eidolon_helvum/ (accessed on 8 June 2021).

123. McFarlane, D.A.; Rentergem, G.V.; Ruina, A.; Lundberg, J.; Christenson, K. Estimating colony size of the wrinkle-lipped bat, Chaerephon plicatus (Chiroptera: Molossidae) at Gomantong, Sabah, by quantitative image analysis. Acta Chiropt. 2015, 17, 171-177. [CrossRef]

124. Richter, H.V.; Cumming, G.S. Food availability and annual migration of the straw-colored fruit bat (Eidolon helvum). J. Zool. 2006, 268, 35-44. [CrossRef]

125. Plowright, R.K.; Foley, P.; Field, H.E.; Dobson, A.P.; Foley, J.E.; Eby, P.; Daszak, P. Urban habituation, ecological connectivity and epidemic dampening: The emergence of Hendra virus from flying foxes (Pteropus spp.). Proc. Biol. Sci. 2011, 278, 3703-3712. [CrossRef]

126. Plowright, R.K.; Peel, A.J.; Streicker, D.G.; Gilbert, A.T.; McCallum, H.; Wood, J.; Baker, M.L.; Restif, O. Transmission or within-host dynamics driving pulses of zoonotic viruses in reservoir-host populations. PLoS Negl. Trop. Dis. 2016, 10, e0004796. [CrossRef]

127. Moreno, K.R.; Weinberg, M.; Harten, L.; Salinas Ramos, V.B.; Herrera Montalvo, L.G.; Czirják, G.Á.; Yovel, Y. Sick bats stay home alone: Fruit bats practice social distancing when faced with an immunological challenge. Ann. N. Y. Acad. Sci. 2021. [CrossRef]

128. Wang, L.-F.; Anderson, D.E. Viruses in bats and potential spillover to animals and humans. Curr. Opin. Virol. 2019, 34, 79-89. [CrossRef]

129. Peixoto, F.P.; Braga, P.H.P.; Mendes, P. A synthesis of ecological and evolutionary determinants of bat diversity across spatial scales. BMC Ecol. 2018, 18. [CrossRef]

130. Fleming, T.H. Bat migration. Encycl. Anim. Behav. 2019, 605-610. [CrossRef]

131. Munshi-South, J.; Wilkinson, G.S. Bats and birds: Exceptional longevity despite high metabolic rates. Ageing Res. Rev. 2010, 9 , 12-19. [CrossRef]

132. Kerth, G. Causes and consequences of sociality in bats. BioScience 2008, 58, 737-746. [CrossRef]

133. Geiser, F.; Stawski, C. Hibernation and torpor in tropical and subtropical bats in relation to energetics, extinctions, and the evolution of endothermy. Integr. Comp. Biol. 2011, 51, 337-348. [CrossRef]

134. Andreassen, H.P.; Sundell, J.; Ecke, F.; Halle, S.; Haapakoski, M.; Henttonen, H.; Huitu, O.; Jacob, J.; Johnsen, K.; Koskela, E.; et al. Population cycles and outbreaks of small rodents: Ten essential questions we still need to solve. Oecologia 2021, 195, 601-622. [CrossRef]

135. Reil, D.; Imholt, C.; Eccard, J.A.; Jacob, J. Beech fructification and bank vole population dynamics-combined analyses of promoters of human Puumala virus infections in Germany. PLoS ONE 2015, 10, e0134124. [CrossRef]

136. Arruda, L.B.; Haider, N.; Olayemi, A.; Simons, D.; Ehichioya, D.; Yinka-Ogunleye, A.; Ansumana, R.; Thomason, M.J.; Asogun, D.; Ihekweazu, C.; et al. The niche of One Health approaches in Lassa fever surveillance and control. Ann. Clin. Microbiol. Antimicrob. 2021, 20. [CrossRef]

137. Calisher, C.H.; Wagoner, K.D.; Amman, B.R.; Root, J.J.; Douglass, R.J.; Kuenzi, A.J.; Abbott, K.D.; Parmenter, C.; Yates, T.L.; Ksiazek, T.G.; et al. Demographic factors associated with prevalence of antibody to Sin Nombre virus in deer mice in the western United States. J. Wildl. Dis. 2007, 43, 1-11. [CrossRef]

138. Owen, R.D. Climate change at a tropical-subtropical interface: Long-term changes in sigmodontine community structure in the Upper Paraná Atlantic Forest, Paraguay. Mastozool. Neotrop. 2021, 28, 1-9. [CrossRef]

139. Owen, R.D.; Goodin, D.G.; Koch, D.E.; Chu, Y.-K.; Jonsson, C.B. Spatiotemporal variation in Akodon montensis (Cricetidae: Sigmodontinae) and hantaviral seroprevalence in a subtropical forest ecosystem. J. Mammal. 2010, 91, 467-481. [CrossRef]

140. Calisher, C.H.; Mills, J.N.; Sweeney, W.P.; Choate, J.R.; Sharp, D.E.; Canestorp, K.M.; Beaty, B.J. Do unusual site-specific population dynamics of rodent reservoirs provide clues to the natural history of hantaviruses? J. Wildl. Dis. 2001, 37, 280-288. [CrossRef]

141. Klein, S.L.; Calisher, C.H. Emergence and persistence of hantaviruses. Curr. Top. Microbiol. Immunol. 2007, 315, 217-252. [CrossRef] 
142. Kane, M.; Golovkina, T. Common threads in persistent viral infections. J. Virol. 2010, 84, 4116-4123. [CrossRef]

143. Meyer, B.J.; Schmaljohn, C.S. Persistent hantavirus infections: Characteristics and mechanisms. Trends Microbiol. 2000, 8, 61-67. [CrossRef]

144. Fulhorst, C.F.; Ksiazek, T.G.; Peters, C.J.; Tesh, R.B. Experimental infection of the Cane Mouse Zygodontomys brevicauda (Family Muridae) with Guanarito virus (Arenaviridae), the etiologic agent of Venezuelan hemorrhagic fever. J. Infect. Dis. 1999, 180, 966-969. [CrossRef]

145. Vitullo, A.D.; Merani, M.S.; Hodara, V.L. Effect of persistent infection with Junin virus on growth and reproduction of its natural reservoir, Calomys musculinus. Am. J. Trop. Med. Hyg. 1987, 37, 663-669. [CrossRef]

146. Vitullo, A.D.; Merani, M.S. Vertical transmission of Junin virus in experimentally infected adult Calomys musculinus. Intervirology 1990, 31, 339-344. [CrossRef]

147. Kang, S.S.; McGavern, D.B. Lymphocytic choriomeningitis infection of the central nervous system. Front. Biosci. 2017, 13, 4529-4543. [CrossRef]

148. Borremans, B.; Vossen, R.; Becker-Ziaja, B.; Gryseels, S.; Hughes, N.; Van Gestel, M.; Van Houtte, N.; Günther, S.; Leirs, H. Shedding dynamics of Morogoro virus, an African arenavirus closely related to Lassa virus, in its natural reservoir host Mastomys natalensis. Sci. Rep. 2015, 5, 10445. [CrossRef]

149. Hoffmann, C.; Wurr, S.; Pallasch, E.; Bockholt, S.; Rieger, T.; Günther, S.; Oestereich, L. Experimental Morogoro virus infection in its natural host, Mastomys natalensis. Viruses 2021, 13, 851. [CrossRef]

150. Walker, D.H.; Wulff, H.; Lange, J.V.; Murphy, F.A. Comparative pathology of Lassa virus infection in monkeys, guinea-pigs, and Mastomys natalensis. Bull. World Health Organ. 1975, 52, 523.

151. Justines, G.; Johnson, K.M. Immune tolerance in Calomys callosus infected with Machupo virus. Nature 1969, 222, 1090-1091. [CrossRef]

152. Ciupe, S.M.; Heffernan, J.M. In-host modeling. Infect. Dis. Model. 2017, 2, 188-202. [CrossRef]

153. Grande-Pérez, A.; Martin, V.; Moreno, H.; de la Torre, J.C. Arenavirus quasispecies and their biological implications. Curr. Top. Microbiol. Immunol. 2016, 392, 231-276.

154. Drake, J.W.; Holland, J.J. Mutation rates among RNA viruses. Proc. Natl. Acad. Sci. USA 1999, 96, 13910-13913. [CrossRef]

155. Sanjuan, R.; Nebot, M.R.; Chirico, N.; Mansky, L.M.; Belshaw, R. Viral mutation rates. J. Virol. 2010, 84, 9733-9748. [CrossRef]

156. Peck, K.M.; Lauring, A.S. Complexities of viral mutation rates. J. Virol. 2018, 92. [CrossRef]

157. Domingo, E. RNA virus evolution, population dynamics, and nutritional status. Biol. Trace Elem. Res. 1997, 56, 23-30. [CrossRef]

158. Lauring, A.S.; Andino, R. Quasispecies theory and the behavior of RNA viruses. PLoS Pathog. 2010, 6, e1001005. [CrossRef]

159. Jonsson, C.B.; Milligan, B.G.; Arterburn, J.B. Potential importance of error catastrophe to the development of antiviral strategies for hantaviruses. Virus Res. 2005, 107, 195-205. [CrossRef]

160. Parrish, C.R.; Holmes, E.C.; Morens, D.M.; Park, E.C.; Burke, D.S.; Calisher, C.H.; Laughlin, C.A.; Saif, L.J.; Daszak, P. Cross-species virus transmission and the emergence of new epidemic diseases. Microbiol. Mol. Biol. Rev. 2008, 72, 457-470. [CrossRef]

161. Wolfe, N.D.; Dunavan, C.P.; Diamond, J. Origins of major human infectious diseases. Nature 2007, 447, 279-283. [CrossRef]

162. Wu, K.; Peng, G.; Wilken, M.; Geraghty, R.J.; Li, F. Mechanisms of host receptor adaptation by Severe Acute Respiratory Syndrome Coronavirus. J. Biol. Chem. 2012, 287, 8904-8911. [CrossRef]

163. Diehl, W.E.; Lin, A.E.; Grubaugh, N.D.; Carvalho, L.M.; Kim, K.; Kyawe, P.P.; McCauley, S.M.; Donnard, E.; Kucukural, A.; McDonel, P.; et al. Ebola virus glycoprotein with increased infectivity dominated the 2013-2016 epidemic. Cell 2016, 167, 1088.e1086-1098.e1086. [CrossRef]

164. Patz, J.A.; Campbell-Lendrum, D.; Holloway, T.; Foley, J.A. Impact of regional climate change on human health. Nature 2005, 438, 310-317. [CrossRef]

165. Horby, P.W.; Hoa, N.T.; Pfeiffer, D.U.; Wertheim, H.F.L. Drivers of Emerging Zoonotic Infectious Diseases. In Confronting Emerging Zoonoses; Springer: Tokyo, Japan, 2014; Volume 26, pp. 13-26. [CrossRef]

166. Smolinkski, M.S.; Hamburg, M.A.; Lederberg, J. Microbial Threats to Health: Emergence, Detection and Response; The National Academies Press: Washington, DC, USA, 2003.

167. Hjelle, B.; Yates, T. Modeling hantavirus maintenance and transmission in rodent communities. Curr. Top. Microbiol. Immunol. 2001, 256, 77-90. [CrossRef]

168. Armién, A.G.; Armién, B.; Koster, F.; Pascale, J.M.; Avila, M.; Gonzalez, P.; de la Cruz, M.; Zaldivar, Y.; Mendoza, Y.; Gracia, F.; et al. Hantavirus infection and habitat associations among rodent populations in agroecosystems of Panama: Implications for human disease risk. Am. J. Trop. Med. Hyg. 2009, 81, 59-66. [CrossRef]

169. Goodin, D.G.; Paige, R.; Owen, R.D.; Ghimire, K.; Koch, D.E.; Chu, Y.K.; Jonsson, C.B. Microhabitat characteristics of Akodon montensis, a reservoir for hantavirus, and hantaviral seroprevalence in an Atlantic forest site in eastern Paraguay. J. Vector Ecol. 2009, 34, 104-113. [CrossRef] [PubMed]

170. Owen, R.D. Temporal variation in small nonvolant mammal (Cricetidae and Didelphidae) microhabitat associations in the Upper Paraná Atlantic Forest. Bol. Mus. Para. Emilio Goeldi Cienc. Nat. 2020, 15, 663-681. [CrossRef]

171. Jonsson, C.B.; Figueiredo, L.T.; Vapalahti, O. A global perspective on hantavirus ecology, epidemiology, and disease. Clin. Microbiol. Rev. 2010, 23, 412-441. [CrossRef]

172. Calisher, C.H.; Sweeney, W.; Mills, J.N.; Beaty, B.J. Natural history of Sin Nombre virus in western Colorado. Emerg. Infect. Dis. 1999, 5, 126-134. [CrossRef] 
173. Ahlm, C.; Alexeyev, O.A.; Elgh, F.; Aava, B.; Wadell, G.; Tarnvik, A.; Juto, P.; Palo, T. High prevalence of hantavirus antibodies in bank voles (Clethrionomys glareolus) captured in the vicinity of households afflicted with nephropathia epidemica. Am. J. Trop. Med. Hyg. 1997, 56, 674-678. [CrossRef]

174. Medina, R.A.; Torres-Perez, F.; Galeno, H.; Navarrete, M.; Vial, P.A.; Palma, R.E.; Ferres, M.; Cook, J.A.; Hjelle, B. Ecology, genetic diversity, and phylogeographic structure of andes virus in humans and rodents in Chile. J. Virol. 2009, 83, 2446-2459. [CrossRef]

175. Meserve, P.L. Three-dimensional home ranges of Cricetid rodents. J. Mammal. 1977, 58, 549-558. [CrossRef]

176. Abramson, G.; Kenkre, V.M.; Yates, T.L.; Parmenter, R.R. Traveling waves of infection in the hantavirus epidemics. Bull. Math. Biol. 2003, 65, 519-534. [CrossRef]

177. Glass, G.E.; Cheek, J.E.; Patz, J.A.; Shields, T.M.; Doyle, T.J.; Thoroughman, D.A.; Hunt, D.K.; Enscore, R.E.; Gage, K.L.; Irland, C.; et al. Using remotely sensed data to identify areas at risk for hantavirus pulmonary syndrome. Emerg. Infect. Dis. 2000, 6, 238-247. [CrossRef]

178. Hjelle, B.; Glass, G.E. Outbreak of hantavirus infection in the Four Corners region of the United States in the wake of the 1997-1998 El Nino-southern oscillation. J. Infect. Dis. 2000, 181, 1569-1573. [CrossRef]

179. Chua, K.B. Nipah virus outbreak in Malaysia. J. Clin. Virol. 2003, 26, 265-275. [CrossRef]

180. Pulliam, J.R.C.; Epstein, J.H.; Dushoff, J.; Rahman, S.A.; Bunning, M.; Jamaluddin, A.A.; Hyatt, A.D.; Field, H.E.; Dobson, A.P.; Daszak, P.; et al. Agricultural intensification, priming for persistence and the emergence of Nipah virus: A lethal bat-borne zoonosis. J. R. Soc. Interface 2012, 9, 89-101. [CrossRef]

181. Chua, K.B.; Chua, B.H.; Wang, C.W. Anthropogenic deforestation, El Niño and the emergence of Nipah virus in Malaysia. Malays. J. Pathol. 2002, 24, 15-21.

182. Hayman, D.T.S. Biannual birth pulses allow filoviruses to persist in bat populations. Proc. Biol. Sci. 2015, $282,20142591$. [CrossRef] [PubMed]

183. Timen, A.; Koopmans, M.P.; Vossen, A.C.; van Doornum, G.J.; Gunther, S.; van den Berkmortel, F.; Verduin, K.M.; Dittrich, S.; Emmerich, P.; Osterhaus, A.D.; et al. Response to imported case of Marburg hemorrhagic fever, the Netherland. Emerg. Infect. Dis. 2009, 15, 1171-1175. [CrossRef]

184. Dimkić, I.; Fira, D.; Janakiev, T.; Kabić, J.; Stupar, M.; Nenadić, M.; Unković, N.; Grbić, M.L. The microbiome of bat guano: For what is this knowledge important? Appl. Microbiol. Biotechnol. 2021, 105, 1407-1419. [CrossRef]

185. Chua, K.B.; Crameri, G.; Hyatt, A.; Yu, M.; Tompang, M.R.; Rosli, J.; McEachern, J.; Crameri, S.; Kumarasamy, V.; Eaton, B.T.; et al. A previously unknown reovirus of bat origin is associated with an acute respiratory disease in humans. Proc. Natl. Acad. Sci. USA 2007, 104, 11424-11429. [CrossRef]

186. Glass, G.E.; Johnson, J.S.; Hodenbach, G.A.; Disalvo, C.L.; Peters, C.J.; Childs, J.E.; Mills, J.N. Experimental evaluation of rodent exclusion methods to reduce hantavirus transmission to humans in rural housing. Am. J. Trop. Med. Hyg. 1997, 56, 359-364. [CrossRef] [PubMed]

187. Childs, J.E.; Glass, G.E.; Ksiazek, T.G.; Rossi, C.A.; Oro, J.G.; Leduc, J.W. Human-rodent contact and infection with lymphocytic choriomeningitis and Seoul viruses in an inner-city population. Am. J. Trop. Med. Hyg. 1991, 44, 117-121. [CrossRef] [PubMed]

188. Childs, J.E.; Glass, G.E.; Korch, G.W.; Ksiazek, T.G.; Leduc, J.W. Lymphocytic choriomeningitis virus infection and house mouse (Mus musculus) distribution in urban Baltimore. Am. J. Trop. Med. Hyg. 1992, 47, 27-34. [CrossRef] [PubMed]

189. Childs, J.E.; Korch, G.W.; Glass, G.E.; LeDuc, J.W.; Shah, K.V. Epizootiology of Hantavirus infections in Baltimore: Isolation of a virus from Norway rats, and characteristics of infected rat populations. Am. J. Epidemiol. 1987, 126, 55-68. [CrossRef] [PubMed]

190. Cline, B.J.; Carver, S.; Douglass, R.J. Relationship of human behavior within outbuildings to potential exposure to Sin Nombre virus in western Montana. Ecohealth 2010, 7, 389-393. [CrossRef] [PubMed]

191. Armstrong, L.R.; Zaki, S.R.; Goldoft, M.J.; Todd, R.L.; Khan, A.S.; Khabbaz, R.F.; Ksiazek, T.G.; Peters, C.J. Hantavirus pulmonary syndrome associated with entering or cleaning rarely used, rodent-infested structures. J. Infect. Dis. 1995, $172,1166$. [CrossRef] [PubMed]

192. Pawan, J.L. The transmission of paralytic rabies in Trinidad by the vampire bat (Desmodus rotundus murinus Wagner. Caribb. Med. J. 1959, 21, 110-136.

193. Gilbert, A.T. Rabies virus vectors and reservoir species. Rev. Sci. Tech. 2018, 37, 371-384. [CrossRef]

194. Pieracci, E.G.; Pearson, C.M.; Wallace, R.M.; Blanton, J.D.; Whitehouse, E.R.; Ma, X.; Stauffer, K.; Chipman, R.B.; Olson, V. Vital Signs: Trends in human rabies deaths and exposures-United States, 1938-2018. MMWR Morb. Mortal Wkly. Rep. 2019, 68, 524-528. [CrossRef]

195. Douron, E.; Moriniere, B.; Matheron, S.; Girard, P.M.; Gonzalez, J.P.; Hirsch, F.; McCormick, J.B. HFRS after a wild rodent bite in the Haute-Savoie-and risk of exposure to Hantaan-like virus in a Paris laboratory. Lancet 1984, 1, 676-677. [CrossRef]

196. Schultze, D.; Lundkvist, A.; Blauenstein, U.; Heyman, P. Tula virus infection associated with fever and exanthema after a wild rodent bite. Eur. J. Clin. Microbiol. Infect. Dis. 2002, 21, 304-306. [CrossRef]

197. Childs, J.E.; Klein, S.L.; Glass, G.E. A Case Study of Two Rodent-Borne Viruses: Not Always the Same Old Suspects. Front. Ecol. Evol. 2019, 7. [CrossRef]

198. Bonwitt, J.; Kelly, A.H.; Ansumana, R.; Agbla, S.; Sahr, F.; Saez, A.M.; Borchert, M.; Kock, R.; Fichet-Calvet, E. Rat-atouille: A mixed method study to characterize rodent hunting and consumption in the context of Lassa fever. EcoHealth 2016, 13, 234-247. [CrossRef] [PubMed] 
199. Ter Meulen, J.; Lukashevich, I.; Sidibe, K.; Inapogui, A.; Marx, M.; Dorlemann, A.; Yansane, M.L.; Koulemou, K.; Chang-Claude, J.; Schmitz, H. Hunting of peridomestic rodents and consumption of their meat as possible risk factors for rodent-to-human transmission of Lassa virus in the Republic of Guinea. Am. J. Trop. Med. Hyg. 1996, 55, 661-666. [CrossRef] [PubMed]

200. Murray, K.; Rogers, R.; Selvey, L.; Selleck, P.; Hyatt, A.; Gould, A.; Gleeson, L.; Hooper, P.; Westbury, H. A novel Morbillivirus pneumonia of horses and its transmission to humans. Emerg. Infect. Dis. 1995, 1, 31. [CrossRef] [PubMed]

201. Murray, K.; Selleck, P.; Hooper, P.; Hyatt, A.; Gould, A.; Gleeson, L.; Westbury, H.; Hiley, L.; Selvey, L.; Rodwell, B.; et al. A morbillivirus that caused fatal disease in horses and humans. Science 1995, 268, 94-97. [CrossRef]

202. Guan, Y.; Zheng, B.J.; He, Y.Q.; Liu, X.L.; Zhuang, Z.X.; Cheung, C.L.; Luo, S.W.; Li, P.H.; Zhang, L.J.; Guan, Y.J.; et al. Isolation and characterization of viruses related to the SARS coronavirus from animals in southern China. Science 2003, 302, 276-278. [CrossRef]

203. Azhar, E.I.; El-Kafrawy, S.A.; Farraj, S.A.; Hassan, A.M.; Al-Saeed, M.S.; Hashem, A.M.; Madani, T.A. Evidence for camel-tohuman transmission of MERS coronavirus. N. Engl. J. Med. 2014, 370, 2499-2505. [CrossRef] [PubMed]

204. Wang, L.F.; Eaton, B.T. Bats, civets and the emergence of SARS. Curr. Top. Microbiol. Immunol. 2007, 315, 325-344. [CrossRef]

205. Hu, B.; Zeng, L.-P.; Yang, X.-L.; Ge, X.-Y.; Zhang, W.; Li, B.; Xie, J.-Z.; Shen, X.-R.; Zhang, Y.-Z.; Wang, N.; et al. Discovery of a rich gene pool of bat SARS-related coronaviruses provides new insights into the origin of SARS coronavirus. PLoS Pathog. 2017, 13, e1006698. [CrossRef] [PubMed]

206. Ithete, N.L.; Stoffberg, S.; Corman, V.M.; Cottontail, V.M.; Richards, L.R.; Schoeman, M.C.; Drosten, C.; Drexler, J.F.; Preiser, W. Close relative of human Middle East respiratory syndrome coronavirus in bat, South Africa. Emerg. Infect. Dis. 2013, 19, 1697-1699. [CrossRef]

207. Corman, V.M.; Ithete, N.L.; Richards, L.R.; Schoeman, M.C.; Preiser, W.; Drosten, C.; Drexler, J.F. Rooting the phylogenetic tree of Middle East Respiratory Syndrome Coronavirus by characterization of a conspecific virus from an African bat. J. Virol. 2014, 88, 11297-11303. [CrossRef] [PubMed]

208. Fehr, A.R.; Channappanavar, R.; Perlman, S. Middle East Respiratory Syndrome: Emergence of a Pathogenic Human Coronavirus. Annu. Rev. Med. 2017, 68, 387-399. [CrossRef]

209. Siegert, R.; Shu, H.L.; Slenczka, H.L.; Peters, D.; Müller, G. The aetiology of an unknown human infection transmitted by monkeys (preliminary communication). Ger. Med. Mon. 1968, 13, 1-2. [PubMed]

210. Smith, C.E.; Simpson, D.I.; Bowen, E.T.; Zlotnik, I. Fatal human disease from vervet monkeys. Lancet 1967, 2, 1119-1121. [CrossRef]

211. Kissling, R.E.; Robinson, R.Q.; Murphy, F.A.; Whitfield, S.G. Agent of disease contracted from green monkeys. Science 1968, 160, 888. [CrossRef]

212. Towner, J.S.; Amman, B.R.; Sealy, T.K.; Carroll, S.A.; Comer, J.A.; Kemp, A.; Swanepoel, R.; Paddock, C.D.; Balinandi, S.; Khristova, M.L.; et al. Isolation of genetically diverse Marburg viruses from Egyptian fruit bats. PLoS Pathog. 2009, 5, e1000536. [CrossRef]

213. Towner, J.S.; Pourrut, X.; Albariño, C.G.; Nkogue, C.N.; Bird, B.H.; Grard, G.; Ksiazek, T.G.; Gonzalez, J.-P.; Nichol, S.T.; Leroy, E.M. Marburg virus infection detected in a common African bat. PLoS ONE 2007, 2, e764. [CrossRef]

214. Swanepoel, R.; Smit, S.B.; Rollin, P.E.; Formenty, P.; Leman, P.A.; Kemp, A.; Burt, F.J.; Grobbelaar, A.A.; Croft, J.; Bausch, D.G.; et al. Studies of reservoir hosts for Marburg virus. Emerg. Infect. Dis. 2007, 13, 1847-1851. [CrossRef]

215. World Health Organization. Ebola haemorrhagic fever in Zaire, 1976. Bull. World Health Organ. 1978, 56, $271-293$.

216. Leirs, H.; Mills, J.N.; Krebs, J.W.; Childs, J.E.; Akaibe, D.; Woollen, N.; Ludwig, G.; Peters, C.J.; Ksiazek, T.G. Search for the Ebola virus reservoir in Kikwit, Democratic Republic of the Congo: Reflections on a vertebrate collection. J. Infect. Dis. 1999, 179, S155-S163. [CrossRef]

217. Reiter, P.; Turell, M.; Coleman, R.; Miller, B.; Maupin, G.; Liz, J.; Kuehne, A.; Barth, J.; Geisbert, J.; Dohm, D.; et al. Field investigations of an outbreak of Ebola hemorrhagic fever, Kikwit, Democratic Republic of the Congo, 1995: Arthropod studies. J. Infect. Dis. 1999, 179, S148-S154. [CrossRef]

218. Le Guenno, B.; Formenty, P.; Wyers, M.; Gounon, P.; Walker, F.; Boesch, C. Isolation and partial characterisation of a new strain of Ebola virus. Lancet 1995, 345, 1271-1274. [CrossRef]

219. Georges, A.-J.; Leroy, E.M.; Renaut, A.A.; Benissan, C.T.; Nabias, R.J.; Ngoc, M.T.; Obiang, P.I.; Lepage, J.P.M.; Bertherat, E.J.; Bénoni, D.D.; et al. Ebola hemorrhagic fever outbreaks in Gabon, 1994-1997: Epidemiologic and Health Control Issues. J. Infect. Dis. 1999, 179, S65-S75. [CrossRef]

220. Leroy, E.M.; Rouquet, P.; Formenty, P.; Souquière, S.; Kilbourne, A.; Froment, J.M.; Bermejo, M.; Smit, S.; Karesh, W.; Swanepoel, R.; et al. Multiple Ebola virus transmission events and rapid decline of central African wildlife. Science 2004, 303, 387-390. [CrossRef]

221. Bausch, D.G.; Towner, J.S.; Dowell, S.F.; Kaducu, F.; Lukwiya, M.; Sanchez, A.; Nichol, S.T.; Ksiazek, T.G.; Rollin, P.E. Assessment of the risk of Ebola virus transmission from bodily fluids and fomites. J. Infect. Dis. 2007, 196, S142-S147. [CrossRef]

222. Young, P.L.; Halpin, K.; Selleck, P.W.; Field, H.; Gravel, J.L.; Kelly, M.A.; Mackenzie, J.S. Serologic evidence for the presence in Pteropus bats of a paramyxovirus related to equine morbillivirus. Emerg. Infect. Dis. 1996, 2, 239-240. [CrossRef]

223. Halpin, K.; Young, P.L.; Field, H.E.; Mackenzie, J.S. Isolation of Hendra virus from pteropid bats: A natural reservoir of Hendra virus. J. Gen. Virol. 2000, 81, 1927-1932. [CrossRef]

224. Chan, Y.P.; Chua, K.B.; Koh, C.L.; Lim, M.E.; Lam, S.K. Complete nucleotide sequences of Nipah virus isolates from Malaysia. J. Gen. Virol. 2001, 82, 2151-2155. [CrossRef]

225. Wang, L.-F.; Yu, M.; Hansson, E.; Pritchard, L.I.; Shiell, B.; Michalski, W.P.; Eaton, B.T. The Exceptionally large genome of Hendra virus: Support for creation of a new genus within the family Paramyxoviridae. J. Virol. 2000, 74, 9972-9979. [CrossRef] 
226. Field, H.; de Jong, C.; Melville, D.; Smith, C.; Smith, I.; Broos, A.; Kung, Y.H.; McLaughlin, A.; Zeddeman, A. Hendra virus infection dynamics in Australian fruit bats. PLoS ONE 2011, 6, e28678. [CrossRef]

227. Rogers, R.J.; Douglas, I.C.; Baldock, F.C.; Glanville, R.J.; Seppanen, K.T.; Gleeson, L.J.; Selleck, P.N.; Dunn, K.J. Investigation of a second focus of equine morbillivirus infection in coastal Queensland. Aust. Vet. J. 1996, 74, 243-244. [CrossRef]

228. Hanna, J.N.; McBride, W.J.; Brookes, D.L.; Shield, J.; Taylor, C.T.; Smith, I.L.; Craig, S.B.; Smith, G.A. Hendra virus infection in a veterinarian. Med. J. Aust. 2006, 185, 562-564. [CrossRef]

229. Williamson, M.M.; Hooper, P.T.; Selleck, P.W.; Gleeson, L.J.; Daniels, P.W.; Westbury, H.A.; Murray, P.K. Transmission studies of Hendra virus (equine morbillivirus) in fruit bats, horses and cats. Aust. Vet. J. 1998, 76, 813-818. [CrossRef]

230. Edson, D.; Field, H.; McMichael, L.; Vidgen, M.; Goldspink, L.; Broos, A.; Melville, D.; Kristoffersen, J.; De Jong, C.; McLaughlin, A.; et al. Routes of Hendra virus excretion in naturally-infected Flying-foxes: Implications for viral transmission and spillover risk. PLOS ONE 2015, 10, e0140670. [CrossRef]

231. Mohd Nor, M.N.; Gan, C.H.; Ong, B.L. Nipah virus infection of pigs in peninsular Malaysia. Rev. Sci. Tech. 2000, 19, 160-165. [CrossRef]

232. Centers for Disease Control and Prevention. Outbreak of Hendra-like virus-Malaysia and Singapore, 1998-1999. MMWR Morb. Mortal Wkly. Rep. 1999, 48, 265-269.

233. Olson, J.G.; Rupprecht, C.; Rollin, P.E.; An, U.S.; Niezgoda, M.; Clemins, T.; Walston, J.; Ksiazek, T.G. Antibodies to Nipah-like virus in bats (Pteropus lylei), Cambodia. Emerg. Infect. Dis. 2002, 8, 987-988. [CrossRef] [PubMed]

234. Yob, J.M.; Field, H.; Rashdi, A.M.; Morrissy, C.; van der Heide, B.; Rota, P.; bin Adzhar, A.; White, J.; Daniels, P.; Jamaluddin, A.; et al. Nipah virus infection in bats (order Chiroptera) in peninsular Malaysia. Emerg. Infect. Dis. 2001, 7, 439-441. [CrossRef]

235. Chua, K.B.; Koh, C.L.; Hooi, P.S.; Wee, K.F.; Khong, J.H.; Chua, B.H.; Chan, Y.P.; Lim, M.E.; Lam, S.K. Isolation of Nipah virus from Malaysian Island flying-foxes. Microbes Infect. 2002, 4, 145-151. [CrossRef]

236. Khan, M.S.; Hossain, J.; Gurley, E.S.; Nahar, N.; Sultana, R.; Luby, S.P. Use of infrared camera to understand bats' access to date palm sap: Implications for preventing Nipah virus transmission. Ecohealth 2010, 7, 517-525. [CrossRef]

237. Hsu, V.P.; Hossain, M.J.; Parashar, U.D.; Ali, M.M.; Ksiazek, T.G.; Kuzmin, I.; Niezgoda, M.; Rupprecht, C.; Bresee, J.; Breiman, R.F. Nipah virus encephalitis reemergence, Bangladesh. Emerg. Infect. Dis. 2004, 10, 2082-2087. [CrossRef]

238. Chadha, M.S.; Comer, J.A.; Lowe, L.; Rota, P.A.; Rollin, P.E.; Bellini, W.J.; Ksiazek, T.G.; Mishra, A. Nipah virus-associated encephalitis outbreak, Siliguri, India. Emerg. Infect. Dis. 2006, 12, 235-240. [CrossRef]

239. Ching, P.K.; de los Reyes, V.C.; Sucaldito, M.N.; Tayag, E.; Columna-Vingno, A.B.; Malbas, F.F., Jr.; Bolo, G.C., Jr.; Sejvar, J.J.; Eagles, D.; Playford, G.; et al. Outbreak of henipavirus infection, Philippines, 2014. Emerg. Infect. Dis. 2015, 21, 328-331. [CrossRef]

240. Walker, D.H.; Murphy, F.A. Pathology and pathogenesis of arenavirus infections. Curr. Top. Microbiol. Immunol. 1987, 133, 89-113. [CrossRef] [PubMed]

241. Enria, D.A.; Pinheiro, F. Rodent-borne emerging viral zoonosis. Hemorrhagic fevers and hantavirus infections in South America. Infect. Dis. Clin. N. Am. 2000, 14, 167-184. [CrossRef]

242. Peters, C.J. Human infection with arenaviruses in the Americas. Curr. Top. Microbiol. Immunol. 2002, 262, 65-74. [CrossRef]

243. Parodi, A.S.; Greenway, D.J.; Rugiero, H.R.; Frigerio, M.; De La Barrera, J.M.; Mettler, N.; Garzon, F.; Boxaca, M.; Guerrero, L.; Nota, N. Concerning the epidemic outbreak in Junin. Dia Med. 1958, 30, 2300-2301.

244. Childs, J.E.; Mackenzie, J.S.; Richt, J.A. Arenaviruses. In Wildlife and Emerging Zoonotic Diseases: The Biology, Circumstances and Consequences of Cross-Species Transmission; Gonzales, J.P., Emonet, S., de Lamballerie, X., Charrel, R., Eds.; Springer Science \& Business Media: Berlin, Germany, 2007; Volume 315.

245. Mills, J.N.; Ellis, B.A.; McKee, K.T., Jr.; Calderon, G.E.; Maiztegui, J.I.; Nelson, G.O.; Ksiazek, T.G.; Peters, C.J.; Childs, J.E. A longitudinal study of Junin virus activity in the rodent reservoir of Argentine hemorrhagic fever. Am. J. Trop. Med. Hyg. 1992, 47, 749-763. [CrossRef]

246. Maiztegui, J.I. Clinical and epidemiological patterns of Argentine haemorrhagic fever. Bull. World Health Organ. 1975, 52, 567-575. [PubMed]

247. Mackenzie, R.B. Epidemiology of Machupo virus infection. I. Pattern of human infection, San Joaquin, Bolivia, 1962-1964. Am. J. Trop. Med. Hyg. 1965, 14, 808-813. [CrossRef]

248. Kuns, M.L. Epidemiology of Machupo virus infection. II. Ecological and control studies of hemorrhagic fever. Am. J. Trop. Med. Hyg. 1965, 14, 813-816. [CrossRef] [PubMed]

249. Mercado, R. Rodent control programmes in areas affected by Bolivian haemorrhagic fever. Bull. World Health Organ. 1975, 52, 691-696. [PubMed]

250. Aguilar, P.V.; Camargo, W.; Vargas, J.; Guevara, C.; Roca, Y.; Felices, V.; Laguna-Torres, V.A.; Tesh, R.; Ksiazek, T.G.; Kochel, T.J. Reemergence of Bolivian hemorrhagic fever, 2007-2008. Emerg. Infect. Dis. 2009, 15, 1526-1528. [CrossRef]

251. Gear, J.S.; Cassel, G.A.; Gear, A.J.; Trappler, B.; Clausen, L.; Meyers, A.M.; Kew, M.C.; Bothwell, T.H.; Sher, R.; Miller, G.B.; et al. Outbreak of Marburg virus disease in Johannesburg. Br. Med. J. 1975, 4, 489-493. [CrossRef]

252. Bausch, D.G.; Nichol, S.T.; Muyembe-Tamfum, J.J.; Borchert, M.; Rollin, P.E.; Sleurs, H.; Campbell, P.; Tshioko, F.K.; Roth, C.; Colebunders, R.; et al. Marburg hemorrhagic fever associated with multiple genetic lineages of virus. N. Engl. J. Med. 2006, 355, 909-919. [CrossRef] 
253. Towner, J.S.; Khristova, M.L.; Sealy, T.K.; Vincent, M.J.; Erickson, B.R.; Bawiec, D.A.; Hartman, A.L.; Comer, J.A.; Zaki, S.R.; Ströher, U.; et al. Marburgvirus genomics and association with a large hemorrhagic fever outbreak in Angola. J. Virol. 2006, 80, 6497-6516. [CrossRef]

254. World Health Organization. Ebola haemorrhagic fever in Sudan, 1976. Bull. World Health Organ. 1978, 56, $247-270$.

255. Frame, J.D.; Baldwin, J.M., Jr.; Gocke, D.J.; Troup, J.M. Lassa fever, a new virus disease of man from West Africa. Am. J. Trop. Med. Hyg. 1970, 19, 670-676. [CrossRef]

256. Monath, T.P. A short history of Lassa fever: The first 10-15 years after discovery. Curr. Opin. Virol. 2019, 37, 77-83. [CrossRef]

257. Dan-Nwafor, C.C.; Ipadeola, O.; Smout, E.; Ilori, E.; Adeyemo, A.; Umeokonkwo, C.; Nwidi, D.; Nwachukwu, W.; Ukponu, W.; Omabe, E.; et al. A cluster of nosocomial Lassa fever cases in a tertiary health facility in Nigeria: Description and lessons learned, 2018. Int. J. Inf. Dis. 2019, 83, 88-94. [CrossRef] [PubMed]

258. Fisher-Hoch, S.P.; Tomori, O.; Nasidi, A.; Perez-Oronoz, G.I.; Fakile, Y.; Hutwagner, L.; McCormick, J.B. Review of cases of nosocomial Lassa fever in Nigeria: The high price of poor medical practice. BMJ 1995, 311, 857-859. [CrossRef]

259. Hamblion, E.L.; Raftery, P.; Wendland, A.; Dweh, E.; Williams, G.S.; George, R.N.C.; Soro, L.; Katawera, V.; Clement, P.; Gasasira, A.N.; et al. The challenges of detecting and responding to a Lassa fever outbreak in an Ebola-affected setting. Int. J. Inf. Dis. 2018, 66, 65-73. [CrossRef]

260. McCormick, J.B.; Webb, P.A.; Krebs, J.W.; Johnson, K.M.; Smith, E.S. Prospective study of the epidemiology and ecology of Lassa fever. J. Infect. Dis. 1987, 155, 437-444. [CrossRef]

261. Overbosch, F.; De Boer, M.; Veldkamp, K.E.; Ellerbroek, P.; Bleeker-Rovers, C.P.; Goorhuis, B.; Van Vugt, M.; Van Der Eijk, A.; Leenstra, T.; Khargi, M.; et al. Public health response to two imported, epidemiologically related cases of Lassa fever in the Netherlands (ex Sierra Leone), November 2019. Eurosurveillance 2020, 25. [CrossRef] [PubMed]

262. Wolf, T.; Ellwanger, R.; Goetsch, U.; Wetzstein, N.; Gottschalk, R. Fifty years of imported Lassa fever: A systematic review of primary and secondary cases. J. Travel Med. 2020, 27. [CrossRef] [PubMed]

263. Bonwitt, J.; Sáez, A.M.; Lamin, J.; Ansumana, R.; Dawson, M.; Buanie, J.; Lamin, J.; Sondufu, D.; Borchert, M.; Sahr, F.; et al. At Home with Mastomys and Rattus: Human-rodent interactions and potential for primary transmission of Lassa virus in domestic spaces. Am. J. Trop. Med. Hyg. 2017, 96, 935-943. [CrossRef] [PubMed]

264. Olayemi, A.; Cadar, D.; Magassouba, N.; Obadare, A.; Kourouma, F.; Oyeyiola, A.; Fasogbon, S.; Igbokwe, J.; Rieger, T.; Bockholt, S.; et al. New hosts of the Lassa virus. Sci. Rep. 2016, 6, 25280. [CrossRef]

265. Núñez, J.J.; Fritz, C.L.; Knust, B.; Buttke, D.; Enge, B.; Novak, M.G.; Kramer, V.; Osadebe, L.; Messenger, S.; Albariño, C.G.; et al. Hantavirus infections among overnight visitors to Yosemite National Park, California, USA, 2012. Emerg. Infect. Dis. 2014, 20, 386-393. [CrossRef]

266. Martinez, V.P.; Bellomo, C.M.; Cacace, M.L.; Suarez, P.; Bogni, L.; Padula, P.J. Hantavirus pulmonary syndrome in Argentina, 1995-2008. Emerg. Infect. Dis. 2010, 16, 1853-1860. [CrossRef]

267. Wells, R.M.; Sosa Estani, S.; Yadon, Z.E.; Enria, D.; Padula, P.; Pini, N.; Mills, J.N.; Peters, C.J.; Segura, E.L. An unusual hantavirus outbreak in southern Argentina: Person-to-person transmission? Hantavirus Pulmonary Syndrome Study Group for Patagonia. Emerg. Infect. Dis. 1997, 3, 171-174. [CrossRef]

268. Song, J.W.; Moon, S.S.; Gu, S.H.; Song, K.J.; Baek, L.J.; Kim, H.C.; Kijek, T.; O'Guinn, M.L.; Lee, J.S.; Turell, M.J.; et al. Hemorrhagic fever with renal syndrome in 4 US soldiers, South Korea, 2005. Emerg. Infect. Dis. 2009, 15, 1833-1836. [CrossRef] [PubMed]

269. Hukic, M.; Kurt, A.; Torstensson, S.; Lundkvist, A.; Wiger, D.; Niklasson, B. Haemorrhagic fever with renal syndrome in north-east Bosnia. Lancet 1996, 347, 56-57. [CrossRef]

270. Clement, J.; Underwood, P.; Ward, D.; Pilaski, J.; LeDuc, J. Hantavirus outbreak during military manoeuvres in Germany. Lancet 1996, 347, 336. [CrossRef]

271. Klein, T.A.; Kang, H.J.; Gu, S.H.; Moon, S.; Shim, S.H.; Park, Y.M.; Lee, S.Y.; Kim, H.C.; Chong, S.T.; O'Guinn, M.; et al. Hantaan virus surveillance targeting small mammals at Dagmar North Training Area, Gyeonggi Province, Republic of Korea, 2001-2005. J. Vector Ecol. 2011, 36, 373-381. [CrossRef]

272. Klein, T.A.; Kim, H.C.; Chong, S.T.; Kim, J.A.; Lee, S.Y.; Kim, W.K.; Nunn, P.V.; Song, J.W. Hantaan virus surveillance targeting small mammals at nightmare range, a high elevation military training area, Gyeonggi Province, Republic of Korea. PLoS ONE 2015, 10, e0118483. [CrossRef]

273. Peters, C.J.; Kuehne, R.W.; Mercado, R.R.; Le Bow, R.H.; Spertzel, R.O.; Webb, P.A. Hemorrhagic fever in Cochabamba, Bolivia, 1971. Am. J. Epidemiol. 1974, 99, 425-433. [CrossRef]

274. Simulundu, E.; Mweene, A.S.; Changula, K.; Monze, M.; Chizema, E.; Mwaba, P.; Takada, A.; Ippolito, G.; Kasolo, F.; Zumla, A.; et al. Lujo viral hemorrhagic fever: Considering diagnostic capacity and preparedness in the wake of recent Ebola and Zika virus outbreaks. Rev. Med. Virol. 2016, 26, 446-454. [CrossRef]

275. Martínez, V.P.; Di Paola, N.; Alonso, D.O.; Pérez-Sautu, U.; Bellomo, C.M.; Iglesias, A.A.; Coelho, R.M.; López, B.; Periolo, N.; Larson, P.A.; et al. "Super-spreaders" and person-to-person transmission of Andes virus in Argentina. N. Engl. J. Med. 2020, 383, 2230-2241. [CrossRef] [PubMed]

276. Chaparro, J.; Vega, J.; Terry, W.; Vera, J.L.; Barra, B.; Meyer, R.; Peters, C.J.; Khan, A.S.; Ksiazek, T.G. Assessment of person-toperson transmission of hantavirus pulmonary syndrome in a Chilean hospital setting. J. Hosp. Infect. 1998, 40, 281-285. [CrossRef]

277. Enría, D.; Padula, P.; Segura, E.L.; Pini, N.; Edelstein, A.; Posse, C.R.; Weissenbacher, M.C. Hantavirus pulmonary syndrome in Argentina. Possibility of person to person transmission. Medicina (B Aires) 1996, 56, 709-711. 
278. Ferres, M.; Vial, P.; Marco, C.; Yanez, L.; Godoy, P.; Castillo, C.; Hjelle, B.; Delgado, I.; Lee, S.J.; Mertz, G.J. Prospective evaluation of household contacts of persons with hantavirus cardiopulmonary syndrome in chile. J. Infect. Dis. 2007, 195, 1563-1571. [CrossRef] [PubMed]

279. Padula, P.J.; Edelstein, A.; Miguel, S.D.; López, N.M.; Rossi, C.M.; Rabinovich, R.D. Hantavirus pulmonary syndrome outbreak in Argentina: Molecular evidence for person-to-person transmission of Andes virus. Virology 1998, 241, 323-330. [CrossRef]

280. Castillo, C.; Villagra, E.; Sanhueza, L.; Ferres, M.; Mardones, J.; Mertz, G.J. Prevalence of antibodies to hantavirus among family and health care worker contacts of persons with hantavirus cardiopulmonary syndrome: Lack of evidence for nosocomial transmission of Andes virus to health care workers in Chile. Am. J. Trop. Med. Hyg. 2004, 70, 302-304. [CrossRef] [PubMed]

281. Institute of Medicine Forum on Microbial Threats. The National Academies Collection: Reports funded by National Institutes of Health. In Learning from SARS: Preparing for the Next Disease Outbreak: Workshop Summary; Knobler, S., Mahmoud, A., Lemon, S., Mack, A., Sivitz, L., Oberholtzer, K., Eds.; National Academies Press (US): Washington, DC, USA, 2004.

282. Zaki, A.M.; Van Boheemen, S.; Bestebroer, T.M.; Osterhaus, A.D.M.E.; Fouchier, R.A.M. Isolation of a novel Coronavirus from a man with pneumonia in Saudi Arabia. N. Engl. J. Med. 2012, 367, 1814-1820. [CrossRef]

283. Cho, S.Y.; Kang, J.-M.; Ha, Y.E.; Park, G.E.; Lee, J.Y.; Ko, J.-H.; Lee, J.Y.; Kim, J.M.; Kang, C.-I.; Jo, I.J.; et al. MERS-CoV outbreak following a single patient exposure in an emergency room in South Korea: An epidemiological outbreak study. Lancet 2016, 388, 994-1001. [CrossRef]

284. Meyer, B.; García-Bocanegra, I.; Wernery, U.; Wernery, R.; Sieberg, A.; Müller, M.A.; Drexler, J.F.; Drosten, C.; Eckerle, I. Serologic assessment of possibility for MERS-CoV infection in equids. Emerg. Infect. Dis. 2015, 21, 181-182. [CrossRef] [PubMed]

285. Reusken, C.B.; Ababneh, M.; Raj, V.S.; Meyer, B.; Eljarah, A.; Abutarbush, S.; Godeke, G.J.; Bestebroer, T.M.; Zutt, I.; Muller, M.A.; et al. Middle East Respiratory Syndrome coronavirus (MERS-CoV) serology in major livestock species in an affected region in Jordan, June to September 2013. Euro Surveill. 2013, 18, 20662. [CrossRef] [PubMed]

286. Delgado, S.; Erickson, B.R.; Agudo, R.; Blair, P.J.; Vallejo, E.; Albarino, C.G.; Vargas, J.; Comer, J.A.; Rollin, P.E.; Ksiazek, T.G.; et al. Chapare virus, a newly discovered arenavirus isolated from a fatal hemorrhagic fever case in Bolivia. PLoS Pathog. 2008, 4, e1000047. [CrossRef] [PubMed]

287. Escalera-Antezana, J.P.; Rodriguez-Villena, O.J.; Arancibia-Alba, A.W.; Alvarado-Arnez, L.E.; Bonilla-Aldana, D.K.; RodríguezMorales, A.J. Clinical features of fatal cases of Chapare virus hemorrhagic fever originating from rural La Paz, Bolivia, 2019: A cluster analysis. Travel Med. Infect. Dis. 2020, 36, 101589. [CrossRef]

288. Salas, R.; de Manzione, N.; Tesh, R.B.; Rico-Hesse, R.; Shope, R.E.; Betancourt, A.; Godoy, O.; Bruzual, R.; Pacheco, M.E.; Ramos, B.; et al. Venezuelan haemorrhagic fever. Lancet 1991, 338, 1033-1036. [CrossRef]

289. Fulhorst, C.E.; Bowen, M.D.; Salas, R.A.; de Manzione, N.M.; Duno, G.; Utrera, A.; Ksiazek, T.G.; Peters, C.J.; Nichol, S.T.; De Miller, E.; et al. Isolation and characterization of pirital virus, a newly discovered South American arenavirus. Am. J. Trop. Med. Hyg. 1997, 56, 548-553. [CrossRef]

290. Smadel, J.E. Epidemic hemorrhagic fever. Am. J. Public Health Nations Health 1953, 43, 1327-1330. [CrossRef] [PubMed]

291. Lee, H.W.; Lee, P.W.; Baek, L.J.; Song, C.K.; Seong, I.W. Intraspecific transmission of Hantaan virus, etiologic agent of Korean hemorrhagic fever, in the rodent Apodemus agrarius. Am. J. Trop. Med. Hyg. 1981, 30, 1106-1112. [CrossRef]

292. Centers for Disease Control and Prevention. Outbreak of acute illness-southwestern United States, 1993. MMWR Morb. Mortal Wkly. Rep. 1993, 42, 421-424.

293. Monath, T.P.; Newhouse, V.F.; Kemp, G.E.; Setzer, H.W.; Cacciapuoti, A. Lassa virus isolation from Mastomys natalensis rodents during an epidemic in Sierra Leone. Science 1974, 185, 263-265. [CrossRef] [PubMed]

294. Paweska, J.T.; Sewlall, N.H.; Ksiazek, T.G.; Blumberg, L.H.; Hale, M.J.; Lipkin, W.I.; Weyer, J.; Nichol, S.T.; Rollin, P.E.; McMullan, L.K.; et al. Nosocomial outbreak of novel Arenavirus infection, southern Africa. Emerg. Infect. Dis. 2009, 15, 1598-1602. [CrossRef] [PubMed]

295. Armstrong, C.; Wallace, J.J.; Ross, L. Lymphocytic Choriomeningitis: Gray Mice, Mus musculus, a Reservoir for the Infection. Public Health Rep. (1896-1970) 1940, 55, 1222. [CrossRef]

296. Armstrong, C.; Lillie, R.D. Experimental Lymphocytic Choriomeningitis of monkeys and mice produced by a virus encountered in studies of the 1933 St. Louis encephalitis epidemic. Public Health Rep. (1896-1970) 1934, 49, 1019. [CrossRef]

297. Johnson, K.M.; Kuns, M.L.; Mackenzie, R.B.; Webb, P.A.; Yunker, C.E. Isolation of Machupo virus from wild rodent Calomys callosus. Am. J. Trop. Med. Hyg. 1966, 15, 103-106. [CrossRef] [PubMed]

298. Lisieux, T.; Coimbra, M.; Nassar, E.S.; Burattini, M.N.; de Souza, L.T.; Ferreira, I.; Rocco, I.M.; da Rosa, A.P.; Vasconcelos, P.F.; Pinheiro, F.P.; et al. New arenavirus isolated in Brazil. Lancet 1994, 343, 391-392. [CrossRef]

299. Ellwanger, J.H.; Chies, J.A. Keeping track of hidden dangers-The short history of the Sabia virus. Rev. Soc. Bras. Med. Trop. 2017, 50, 3-8. [CrossRef] 